\title{
ÖRGÜTSEL VATANDAŞLIK DAVRANIŞININ ÖNCÜLÜ OLARAK OKUL YÖNETICILERİNIN KULLANDIKLARI GÜÇ KAYNAKLARI ${ }^{1}$
}

\author{
POWER USED BY SCHOOL ADMINISTRATORS AS PIONERS ON \\ ORGANIZATIONAL CITIZENSHIP BEHAVIOR
}

\section{Celal Teyyar UĞURLU ${ }^{2}$}

Ahsen DEMIR ${ }^{3}$

\section{Öz}

$\mathrm{Bu}$ çalışmada öğretmenlerin örgütsel vatandaşlık davranışları ve yöneticilerin güç kullanımının öğretmen görüşlerine göre betimlenmesi ve güç kullanımının örgütsel vatandaşlık davranışları üzerindeki etkisi incelenmiştir. Araştırmanın çalışma grubunu Sivas ilinde yirmi ortaokul oluşturmaktadır. Geri dönen ve işlenmeye uygun ölçekler aracılığıyla toplanan verilerle istatistik işlemler gerçekleştirilmiştir. Araştırma verilerinin çözümlenmesinde, betimsel istatistik yöntemlerinden yararlanılmıştır. Araştırma verilerinin analizinde; t testi, Tek Yönlü (one way) Varyans Analizi (ANOVA) ve regrasyon analizleri yapılmıştır. Araştırma sonuçlarına göre, öğretmenlerin örgütsel vatandaşlık davranışları yüksek, yöneticilerin güç kullanımı orta düzeydedir. Yöneticinin kullandığı güç tipi örgütsel vatandaşlık davranışı ile düşük düzeyde anlamlı ilişki olduğu bulunmuştur. Araştırma sonucunda öğretmenlerin örgütsel vatandaşlık davranışlarını artırmak için yapılacak çeşitli faaliyetlerin yanı sıra güç kullanımına da dikkat edilmesi öneri olarak sunulabilir.

Anahtar Kelimeler: Güç, okul, örgütsel vatandaşlık.

\begin{abstract}
In this study, organizational citizenship behaviours of teachers, the influence of power used by administrators and organizational citizenship behaviour is described according to teachers' views. Study group of the research is twenty secondary schools in Sivas. Returnees and the data collected with the appropriate scale processed with statistical procedures were carried out. To analyse the data, descriptive statistical methods were used. For the analysis of the data; t-test, One-way analysis of variance (ANOVA) and regression analysis were performed. According to the survey results, organizational citizenship behaviours of teachers were high and the use of executive power was moderate. Power used by the principal type was found significantly associated with lower levels of organizational citizenship behaviour. Of teachers in the survey, results were found improving the organizational citizenship behaviour and it can be submitted as a proposal to be considered in the use of power as well as a variety of other activities.
\end{abstract}

Keywords: Power, school, organizational citizenship. the use of power

\footnotetext{
${ }^{1}$ Bu çalışma Doç.Dr. Celal Teyyar UĞURLU danışmanlığında Ahsen Demir'in Yüksek Lisans tez çalışmasının nicel kısmıdır.

${ }^{2}$ Doç.Dr. Cumhuriyet Üniversitesi, Eğitim Fakültesi, Eğitim Bilimleri Bölümü, celalteyyar@yahoo.com

${ }^{3}$ Uzman, Milli Eğitim Müdürlüğü, Sivas ahsen.demir@gmail.com
} 


\section{GÍRİŞ}

\subsection{Güç}

Sosyal bir terim olan güç (Polat, 2010) karş1lıklı etkileşimin olduğu her yer ve zamanda kendini göstermektedir (Bağcı ve Bursalı, 2011). Aydın'ın (2013) insanlar işbirliği içerisinde çalışırken, amacı gerçekleştirici eylemin başlatılması ve sürdürülmesi için gereken temel enerji olarak tanımladığı gücün literatürde yer alan tanımlarında ortak yönler göze çarpmaktadır. Hemen hemen yapılan tüm tanımlara göre güç, istenilen sonucu elde etmek amacıyla başkalarını etkileyebilme yeteneği (Özdemir, 2013; Aslanargun ve Eriş, 2013; Hoy ve Miskel, 2010; Bağc1 ve Bursal1, 2011; Gökkaya, 2010; Schermerhorn, Hunt ve Osborn, 2000, Aldemir, 1983; Erdoğan, 1997) olarak tanımlanmaktadır.

Güç, etkileme yeteneği olarak tanımlanmakta iken, etkileme bu yeteneğin sonuca dönüşmesidir (Aslanargun, 2013). Güç başkalarını etkileyebilme yeteneğidir. Bireylerin başkalarını etkileyebilmek için faydalandıkları kaynaklar ise güç kaynaklarıdır (Özdemir 2013). Güç, örgüt içerisinde hedeflenen faaliyetleri, istendik davranışları, örgütsel öğrenmeyi etkileyen ve istikrarı sağlayan en önemli enstrümandır (Gökkaya, 2010).

İnsanoğlunun karakteristik özellikleri birbirinden farklı olduğundan hepsini aynı şekilde etkilemek mümkün değildir. Farklı güç kaynakları etkilemede bir araç olarak kullanılabilir. French ve Raven'in saptadıkları güç tipleri şunlardır: Ödül gücü, ceza gücü, yasal (orun) güç, uzmanlık gücü, çekicilik (özdeşleşme, karizmatik) gücü (Aldemir, 1983). French ve Raven'in taksonomisi esas alınarak, daha sonraları bu taksonomiye bilgi gücünü eklemişdir (Özaslan, 2006).

Schermerhorn, Hunt ve Osborn'a (2000) göre, yöneticiler gücü hem örgütsel hem de kişisel kaynaklardan elde ederler (Koşar 2008). Yasal, zorlayıcı ve ödül gücü resmi otoriteden kaynaklanırken, karizma ve uzmanlık gücü ise kişisel özelliklerden kaynaklanmaktadır (Demirel, 2012; Uzun, 2008; Koşar, 2008; Robbins, 1994). Yasal güç liderin hiyerarşik yap1 içindeki konumuna ya da rolüne bağlı olarak sahip olduğu yetkiye dayalı etkileyebilme gücüdür (Yılmaz ve Altınkurt, 2013; Altınkurt ve Y1lmaz, 2012b; Uzun, 2008; Kulu, 2008; Özaslan, 2006; Erdoğan, 1997). Yönetici makamının gerektirdiği işleri yapma ve yaptırma hakkını kullanarak yönetsel gücü kazanmaktadır (Altınkurt ve Yılmaz, 2012b). Ödül gücü, temelde yöneticilerde bulunan, kişinin, karşısındaki kişi veya gruba çeşitli ödüller sunabilme veya bu ödüllerden mahrum birakabilme gücüdür. Yöneticiler, bulundukları pozisyon gereğince maddi bazı ödüller sunabilir veya bu ödülleri vermeyerek cezalandırabilirler (Erdoğan, 1997). Zorlayıcı güç, liderin direktiflerine karşı astların karşı gelmesi durumunda kontrol etme ve cezalandırma gücünü yansıtmaktadır (Bakan ve Büyükmeşe, 2010; Kulu, 2008). Ödül gücünün karşıtı olan bir güç türüdür (Altınkurt ve Yılmaz, 2012b; Bakan ve Büyükmeşe, 2010; Kulu, 2008; Açıkalın, 1993). Uzmanlık gücü grubun ihtiyaçlarını karş1lamaya yönelik olarak liderin sahip olduğu özel yetenek ve bilgilerdir (Uzun, 2008). Karizmatik güç ise kişinin çeşitli kişisel özelliklerinin astlarını etkileyebilmesi (Altınkurt ve Y1lmaz 2013; Bakan ve Büyükmeşe, 2010; Polat, 2010; Bayrak, 2001; Erdoğan,1997; Aldemir, 1983), astların bu özellikler nedeniyle kendilerini bu kişi ile özdeşleştirmeleri, ona benzemek istemeleri ve onun gibi olmak istemeleri sonucu ortaya çıkar (Erdoğan, 1997).

Yöneticilerin kullandıkları güç tipleri astlarının örgütün amaçlarına yönelik davranışları etkilemektedir (Somech ve Zahavy, 2002). Özellikle de örgütün gelişmesi için istenen örgütsel vatandaşlık davranışlarına etki etmektedir. Örgütsel vatandaşlık davranış1 Zengin'e göre (2011) herhangi bir baskı ya da zorlama olmaksızın, gönüllü olarak yapılan, içten gelen, herhangi bir ödül ya da menfaat beklentisi olmadan isteğe bağlı olarak yapılan davranışlardır. Örgütsel vatandaşlık davranışlarında, kişilerin görevleri dışında yaptıkları fazladan bir çaba ve çalışma söz konusu olduğu için bu çalışmaları belirleyen belli yasa ya da 
kurallar yoktur. Tamamen kişilerin tercihlerine bağlı ortaya çıkan davranışlardır. (Nar, 2009; Öztürk, 2009; Kayan, 2008; Ay, 2007; Samanc1, 2006).

Örgütsel Vatandaşlık Davranışları (ÖVD)'nın kuruma katkılarını şu şekilde sıralayabiliriz:

Tablo 1. Literatüre Göre ÖVD' nin Sonuçları

\begin{tabular}{|c|c|}
\hline Katkılar & Yazar \\
\hline $\begin{array}{l}\text { Örgüt üyeleri örgütlerine duygusal olarak bağlandıkları için çalışma } \\
\text { ortamına duyulan bağlılığın artması }\end{array}$ & $\begin{array}{l}\text { Zengin 2011, Aktay, 2008; } \\
\text { Samanc1, } 2006\end{array}$ \\
\hline $\begin{array}{l}\text { Örgüt üyelerinin iş doyumunun, sorumluluğunun, dayanışmasının, işbirliği } \\
\text { yapma eğiliminin, karara katılmada gönüllüğünün artması }\end{array}$ & Zengin, 2011; Polat, 2007 \\
\hline Görüşlerinin önem verildiğini gördüğünde üretkenliği artması & Zengin, 2011 \\
\hline Sorunların ortaya çıkması önlenmesi & Zengin, 2011 \\
\hline Örgüt yaşamına katılımda gönüllülügüun artması & Zengin, 2011 \\
\hline Örgüt üyelerinin örgütlerine olan sorumluluk hissini arttırma & Zengin, 2011 \\
\hline $\begin{array}{l}\text { Kurum içinde hem yardım edenin hem de yardım edilenin iş tatmini } \\
\text { artması }\end{array}$ & $\begin{array}{l}\text { Gök, 2010; Aktay, 2008; } \\
\text { Samanc1, } 2006\end{array}$ \\
\hline Motivasyon artmasi & Aktay, 2008; Samanc1, 2006 \\
\hline Çalışmanın sonucunda kalite ortaya çıkması & Aktay, 2008; Samanc1, 2006 \\
\hline Örgüt performansının sürekliliği sağlanması & Aktay, 2008; Samanc1, 2006 \\
\hline Örgütün değişen çevre koşullarına adaptasyonu kolaylaşması & $\begin{array}{l}\text { Özkan, 2012; Uslu, 2011; } \\
\text { Aktay, 2008; Samanc1, 2006; } \\
\text { Polat, } 2007\end{array}$ \\
\hline Çalışanlarının ve örgütün verimliliğini arttırması & $\begin{array}{l}\text { Özkan, 2012; Uslu, 2011; } \\
\text { Aktay, 2008; Samanc1, 2006; } \\
\text { Polat, } 2007\end{array}$ \\
\hline Örgütün işgücünü çekme ve elinde tutma yeteneğinin artması & Polat, 2007 \\
\hline Öğrenen örgüt kimliğine ulaşmayı kolaylaştırması & Uslu, 2011 \\
\hline Örgütün yetenekli çalışanlarını bünyesinde tutmasını sağlaması & Özkan, 2012; Uslu, 2011 \\
\hline Örgütlerde olumlu bir iklimin gelişmesine katkı sağlama & Büyüközkan, 2012 \\
\hline Bireysel ve örgütsel amaçlara ulaşmada dengeleyici bir etken olma & Uslu, 2011 \\
\hline
\end{tabular}

Bireysel ve örgütsel etkililiğe katkıda bulunan ÖVD’nin okul açısından ne anlama geldiğinin bilinmesi, öğretmen, yönetici ve okula taraf olan diğer tüm kesimlerin davranışlarının, okulun amaçları doğrultusunda daha iyi analiz edilmesini sağlayabilir (Sezgin, 2005).

\subsection{Güç, Örgütsel Vatandaşlık Davranışı ve Eğitim}

Eğitim örgütleri söz konusu olduğunda her düzeyde eğitim hizmeti sunan okullar ve kurumlar akla gelmektedir (Aslanargun, 2008). Özellikle eğitim örgütlerinde gücün doğru kullanımı çok önemlidir. Çünkü hammadde insandır. Yanlış metot, hatalı üretim öğrenciler üzerinde derin izler bırakabileceği gibi bir milletin geleceği açısından düzeltilmesi çok ağır neticeler doğurabilir (Göksu, 2004). Okul müdürlerinin yönetimde yanında çalışan personeline karşı sahip olduğu güç bir satranç oyunundaki şah'ın gücüyle eş değerdir. $\mathrm{O}$ yüzden sahip olduğu gücün farkında olması ve bunu eğitimin amaçlarına en uygun biçimde 
kullanması çok önemlidir (Üstün, 2013). Gücü olmayan veya sahip olduğu gücü etkili kullanamayan yöneticiler, bütün işleri kendisi yapmak zorunda kalabilir. Diğer bir ifadeyle güç, yöneticiyi harekete geçiren en temel yönetim organı ve iş yaptırma aracı olarak ifade edilebilir (Aslanargun, 2008).

Okullarda kullanılacak güç temellerine aşırı özen gösterilmesi gerekmektedir. Gevşek yapılı ve değer merkezli örgütler olan okullarda, okul müdürlerinin kullandığı gücün temellerinin belirlenmesi bu kurumların çözümlenmesi açısından çok önemlidir. (Altınkurt ve Yılmaz, 2013). Okullarda yönetsel eylem ve işlemlerde bulunan okul müdürlerinin başarısı, elindeki güç kaynaklarını etkin biçimde kullanarak çevresindekileri etkileyebilmesine bağlıdır (Kayal1, 2011). Okul yöneticilerinin, etkili yönetim becerileri sergileyebilmek, öğretmenlerin motivasyonlarını artırmak ve onlarda bir farkındalık yaratabilmek için, kullandıkları güç tiplerine öğretmenlerin verebileceği tepkileri önceden kestirebilmeleri, etkililik ve verimlilik açılarından önemli olarak kabul edilebilir. Bu anlamda okul yöneticilerinin en uygun güç tipini tercih edebilen ve gerektiğinde, gücü paylaşma yetisine sahip profesyonel bir yönetici olmaları beklenebilir (Polat, 2010; Koşar, 2008).

Yöneticilerin aşırı miktarda güç sahibi olmaları veya gücünü kötüye kullanmaları çalışanlarla yönetici arasındaki uzaklığın artmasına neden olmaktadır (Özaslan, 2006). Çalışanlar bu durumdan etkilenerek örgütten ayrılmak isteyebilirler veya ayrılma gibi bir imkanları bulunmazsa güce uyum göstermek zorunda kalabilirler. Bahsedilen iki durumda da örgüt elemanları rol dışı olan ekstra rol davranışlarını sekteye uğratmaktadır. Örneğin, yöneticinin zorlayıcı güç türünü kullanması öğretmenin okulda bulunma süresini kısaltacak, gönüllü işlere katılma oranını azaltacak dolayısıyla örgütsel vatandaşlık davranışı (ÖVD) olan sivil erdem davranışlarını kesintiye uğratacaktır. Bu durumda örgüt ekstra rol davranışları aracılığı ile hedeflerine daha kısa sürede ulaşabilecekken, belirlenen süre içerisinde hedeflerine ulaşamayabilecek hale gelebilir. $\mathrm{Bu}$ durum okullar da dahil olmak üzere tüm örgütler için istenmeyen bir durumdur.

$\mathrm{Bu}$ çalışmada okul yöneticilerinin güç kullanımını ve kullandığı güç türünü, öğretmenlerin örgütsel vatandaşlık davranışları ile bu davranışların alt boyutlarının düzeyini nicel olarak betimlemektir. Ayrıca okul yöneticilerinin kullandığı güç türleri ile öğretmenlerin örgütsel vatandaşlık davranışları arasındaki ilişkinin düzeyini ve okul yöneticisinin kullandığı gücün öğretmenlerin örgütsel vatandaşlık davranışlarının yordayıcısı olup olmadığını nicel olarak ortaya çıkarmaktır. Bu amaçla bu çalışmada aşağıdaki sorulara yanıt aranmıştır:

1. Öğretmenlerin örgütsel vatandaşlık algıları ile yöneticilerin güç kullanım düzeyleri nicel olarak nasıldır?

2. Öğretmenlerin örgütsel vatandaşlık algıları yöneticilerinin güç kullanım düzeyleri cinsiyet ve son çalıştı̆̆ okuldaki hizmet süresine göre farklılık göstermekte midir?

3. Öğretmenlerin örgütsel vatandaşlık davranışları algıları ile yöneticilerinin güç kullanım düzeyleri arasındaki ilişki nasıldır?

4. Yöneticilerin güç kullanım düzeyleri öğretmenlerin örgütsel vatandaşlık davranışlarının ne kadarını açıklamaktadır?

\section{YÖNTEM}

\subsection{Araştırmanın Modeli}

$\mathrm{Bu}$ çalışma yöneticilerin güç tipi tercihlerinin örgütsel vatandaşlık davranışı üzerindeki etkisini ortaya çıkarmayı amaçlayan betimsel bir çalışmadır. Betimsel çalışma şu anki durumu ortaya koymak için yapılan çalışmalardır (Balcı, 2005; Cohen, Manion and Morrison 2000). Yönetici güç kullanımının örgütsel vatandaşlık davranışı üzerindeki etkisi 
betimsel tarama modeli ile belirlenmeye çalışılan bu çalışmada araştırma modeli şu şekilde oluşturulmuştur:

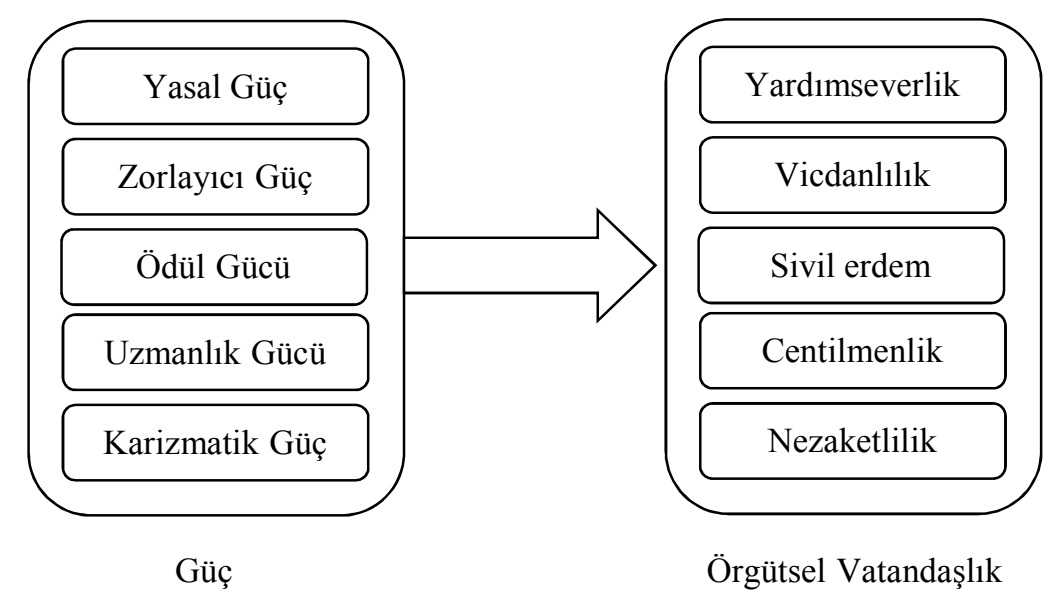

Şekil 1: Araştırmanın Modeli

$\mathrm{Bu}$ çalışmada betimsel nitelikte ilişkisel tarama yöntemi kullanılmıştır. Karasar'a göre (2005) tarama modellerinin amacı, geçmişte ya da halen varolan bir durumu betimlemektir. İlişkisel tarama modeli ise iki veya daha çok sayıdaki değişken arasında birlikte değişimin varlığını ve/veya derecesini belirlemeyi amaçlar.

\section{2. Çalışma Grubu}

Araştırmanın çalışma grubunu Sivas ilinde görev yapmakta olan öğretmenler oluşturmaktadır. Araştırmada, nicel boyut için, çalışma grubu küme örnekleme yoluyla seçilmiş ve veri toplama aracı 20 okuldaki tüm öğretmenlere dağıtılmış, öğretmenlerden geri dönen ve işlemeye uygun olanlar belirlenmiştir (Büyüköztürk, Çakmak, Akgün ve Demirel, 2012). Nicel çalışma grubuna ilişkin özellikler Tablo 4 'te verilmiştir.

Tablo 2. Nicel Boyuta İlişkin Çalışma Grubu Özellikleri

\begin{tabular}{cccc}
\hline \hline & Değişkenler & f & \% \\
\hline \hline \multirow{2}{*}{ Cinsiyet } & Kadın & 124 & 58.5 \\
\cline { 2 - 4 } & Erkek & 88 & 41.5 \\
\hline \multirow{2}{*}{ Branş } & Sınıf & 79 & 37.3 \\
\cline { 2 - 4 } & Branş & 133 & 62.7 \\
\cline { 2 - 4 } & 5 yıldan az & 91 & 42.9 \\
\cline { 2 - 4 } & 5-10 yıl & 52 & 24.5 \\
\cline { 2 - 4 } & $11-15$ yıl & 27 & 12.7 \\
\cline { 2 - 4 } & $16-20$ yıl & 22 & 10.5 \\
\cline { 2 - 4 } & $21-25$ yıl & 9 & 4.2 \\
\cline { 2 - 4 } & 26 yıl ve üzeri & 11 & 5.2 \\
\hline \multirow{2}{*}{ Okul türü } & İlkokul & 96 & 45.3 \\
\cline { 2 - 4 } & Ortaokul & 116 & 54.7 \\
\hline
\end{tabular}




\subsection{Veri Toplama Araçları}

Araştırmada iki değişken olduğundan veri toplama aracı olarak iki ölçek kullanılmıştır. Yöneticilerin güç stillerini ölçmek için Yılmaz ve Altınkurt'un (2013) geliştirdiği "Okullarda Örgütsel Güç Ölçeği" (OÖGÖ) kullanılmıştır. Araştırmacılar maddelerin yazımında, konu ile ilgili önceki çalışmalardan, uzman görüşlerinden ve okul müdürlerinin görüşlerinden yararlanarak 47 madde yazmışlardır. Uzman görüşleri alındıktan sonra maddelerde eleme yapılarak maddeler 40'a indirilmiştir. Ölçekte "1-hiçbir zaman, 2-çok nadir, 3-bazen, 4-çoğunlukla ve 5-her zaman" seçeneklerinden oluşan Likert tipi beşli derecelendirme ölçeği kullanılmıştır. Beş alt boyuttan oluşan ölçeğin 1-4 soruları 'yasal', 5-11 soruları 'ödül', 12-21 soruları 'zorlayıcı', 22-29 soruları 'uzmanlık', 30-37 soruları 'karizma' alt boyutlarını ölçmektedir. Araştırmacılar tarafından ölçeğin güvenirliği için Cronbach Alpha ve McDonald'ın $\omega$ iç tutarlık katsayısı ile madde toplam korelasyonları incelenmiştir. OÖGÖ’nün "Yasal Güç" faktöründe maddelerin madde-toplam korelasyonları 0.57 ile 0.71 arasında, "Ödül Gücü" faktöründe 0.50 ile 0.81 arasında, "Zorlayıcı Güç" faktöründe 0.43 ile 0.76 arasında, "Uzmanlık Gücü" faktöründe 0.71 ile 0.85 arasında ve "Karizma Gücü" faktöründe 0.75 ile 0.84 arasında değişmektedir. OÖGÖ’nün ilk faktörü olan "Yasal Güç" faktörüne ilişkin Cronbach Alpha iç tutarlılık katsayısı 0.84, McDonald'ın $\omega$ iç tutarlılık katsayısı 0.83 'dür. Bu katsayılar sırasıyla ikinci faktör olan “Ödül Gücü” faktörü için $\alpha=0.89$, $\omega=0.89$; üçüncü faktör olan "Zorlayıcı Güç" faktörü için $\alpha=0.91, \omega=0.91$; dördüncü faktör olan "Uzmanlık Gücü” ve beşinci faktörü olan "Karizma Gücü” faktörleri için ise $\alpha$ ve $\omega$ 0.94'tir. Özetle faktörler için $\alpha$ katsayılarının 0.84-0.94, $\omega$ katsayılarının 0.83-0.94 arasında değiştiği görülmektedir. Hesaplanan iç tutarlılık katsayıları ölçeğin güvenirliğinin yüksek düzeyde olduğunu göstermektedir.

Araştırmada öğretmenlerin örgütsel vatandaşlık davranışlarını ölçmek için Polat'ın (2007) geçerlik ve güvenirliğini doğruladığı "Örgütsel Vatandaşlık Ölçeği" kullanılmıştır. Ölçek dört alt boyuttan oluşmakta olup ölçeğin 1-8 soruları 'yardımlaşma', 9-12 soruları 'centilmenlik' 13-16 soruları 'vicdanlılık', 17-20 soruları 'sivil erdem' boyutlarını ölçmektedir. Polat (2007) tarafından yapılan güvenirlik analizinde tüm ölçeğin Cronbach's Alpha katsayısı .89 olarak hesaplamıştır. Yapılan faktör analizine dayalı boyutlar için yapılan güvenirlik hesabında ise yardımlaşma boyutunda .86 ; centilmenlik boyutunda .81 ; vicdanlılık boyutunda .88 ve sivil erdem boyutunda ise .82 bulunmuştur. Yapılan faktör analizinde ise, asl1 5 boyutlu olan ölçek, 4 boyutta toplamıştır. Ölçeğin aslındaki yardımlaşma ve nezaket boyutunda yer alan maddeler, yardımlaşma ve nezaket boyutunun iç içe olduğunu ortaya koyan literatüre dayandırılarak bir boyutta toplanmıştır.

\subsection{Verilerin Analizi}

Araştırmada öğretmenlerin örgütsel vatandaşlık davranışı, yönetici güç algıları ve bunların alt boyutlarına ait değişkenlere ilişkin algı düzeylerini saptamak için aritmetik ortalamaya bakılmıştır. Aritmetik ortalamalar yorumlanırken aralıklar Örgütsel Güç Kaynağı Ölçeği ve Örgütsel Vatandaşlık Ölçeği için 1.00-1.79 "oldukça düşük", 1.80-2.59 "düşük", 2.60-3.39 “orta", 3.40-4.19 "yüksek", 4.20-5.00 aralığ1 ise "oldukça yüksek" olarak değerlendirilmiştir. Araştırmanın nicel boyutuyla ilgili elde edilen veriler SPSS 21.0 programı kullanılarak çözümlenmiştir. Verilerin normal dağılıma sahip olup olmadığını test etmek için Shapiro-Wilk ve Kolmogorov-Simirnov testleri kullanılarak ayrica bunlara ait skewness (çarpıklık) ve kurtosis (basıklık) değerleri hesaplanmıştır. Örgütsel vatandaşlık davranışı ve güç kullanımının alt boyutlarına ait skewness (çarpıklık) ve kurtosis (basıklık) değerleri Tablo 3'te verilmiştir. 
Tablo 3. Örgütsel Vatandaşlık Davranışına ve Güç Kullanımına İlişkin Çarpıklık Basıklık Değerleri

\begin{tabular}{lccccc}
\hline & $\mathrm{N}$ & \multicolumn{2}{c}{ Skewness (çarpıklık) } & \multicolumn{2}{c}{ Kurtosis (basıklık) } \\
\hline & & İstatistik & Standart hata & İstatistik & Standart hata \\
Vatandaşlık & 212 &,- 260 &, 167 &, 760 &, 333 \\
Yardımlaşma & 212 & $-1,333$ &, 167 & 4,320 &, 333 \\
Vicdanlılık & 212 &,- 845 &, 167 &, 543 &, 333 \\
Sivil erdem & 212 &,- 115 &, 167 &,- 132 &, 333 \\
Güç & 212 &,- 472 &, 167 &, 394 &, 333 \\
Yasal & 212 &,- 750 &, 167 &, 457 &, 333 \\
Ödül & 212 &,- 617 &, 167 &, 214 &, 333 \\
Zorlayıcı & 212 &, 495 &, 167 &,- 537 &, 333 \\
Uzmanlık & 212 &,- 836 &, 167 &, 587 &, 333 \\
Karizmatik & 212 &,- 592 &, 167 &,- 434 &, 333 \\
Centilmenlik & 212 & $-1,065$ &, 167 & 1,080 &, 333 \\
\hline
\end{tabular}

Tablo 3 incelendiğinde örgütsel vatandaşlık davranışının yardımseverlik boyutu hariç diğer boyutların çarpıklık basıklık katsayıları +3 ile -3 arasında değişim göstermektedir. $\mathrm{Bu}$ değerler dağılımların normal olduğunu göstermektedir (Çepni, 2010). Yardımseverlik boyutuna ait veriler ise uzman görüşü alındıktan sonra verilerin normal dağılım gösterdiği varsayılmıştır. Analizlerde .05 anlamlılık düzeyi temel alınmıştır. Cinsiyet değişkeni açısından deneklerin ölçek maddelerine verdikleri yanıtlar arasında anlamlı bir fark olup olmadığını test etmek amacıyla parametrik testlerden $\mathrm{t}$ testi yapılmıştır. Okuldaki hizmet süresi değişkeni açısından deneklerin ölçek maddelerine verdikleri yanıtlar arasında anlamlı bir fark olup olmadığını test etmek amacıyla parametrik testlerden tek yönlü varyans (ANOVA) kullanılmıştır. Araştırma okul yöneticilerinin kullandığı güç ve gücün boyutları ile öğretmenlerin örgütsel vatandaşlık davranışları ve alt boyutlarının ne kadar etkilediğini, güç kullanımının vatandaşılık davranışının ne kadarını açıkladığını test etmek için çoklu regresyon analizi yapılmıştır.

\section{BULGULAR}

\section{1. Öğretmenlerin Örgütsel Vatandaşlık Algıları ile Yöneticilerin Güç Kullanım Düzeylerine İlişkin Bulgular}

Tablo 4'te öğretmenlerin örgütsel vatandaşlık davranışına ve öğretmenlerin algısına göre yöneticilerin güç kullandığı güç tiplerine ilişkin ortalamalar ve standart sapmalar verilmiştir. 
Tablo 4. Öğretmenlerin Örgütsel Vatandaşlık Davranışı ve Yönetici Güç Tipine İlişkin Aritmetik Ortalama ve Standart Sapmalar

\begin{tabular}{|c|c|c|}
\hline Değişkenler & $\overline{\bar{x}}$ & SS \\
\hline Örgütsel vatandaşlık & 3,66 & ,33 \\
\hline Yardımlaşma & 4,11 &, 57 \\
\hline Vicdanlılık & 4,32 &, 57 \\
\hline Sivil erdem & 3,94 &, 59 \\
\hline Centilmenlik & 3,66 &, 33 \\
\hline Güç & 3,36 & ,49 \\
\hline Yasal & 4,06 & ,71 \\
\hline Ödül & 3,60 &, 84 \\
\hline Zorlayıcı & 2,50 & ,92 \\
\hline Uzmanlık & 3,75 & ,91 \\
\hline Karizmatik & 3,75 & ,90 \\
\hline
\end{tabular}

Tablo 4' e göre genel olarak öğretmenlerin örgütsel vatandaşlık davranışları algılanı $(\bar{x}=3,66)$ "yüksek" düzeydedir. Öğretmenlerin örgütsel vatandaşlık davranışının yardımlaşma alt boyutuna ait alg1ları $(\bar{x}=4,11)$ "yüksek", vicdanlılık alt boyutuna ait algıları $(\bar{x}=4,32)$ "oldukça yüksek", sivil erdem alt boyutuna ait algıları $(\bar{x}=3,94)$ "yüksek", centilmenlik alt boyutuna ait algıları $(\bar{x}=3,66)$ "yüksek" düzeydedir.

Öğretmenlerin algılarına göre genel olarak yöneticilerin güç kullanımları $(\bar{x}=3,36)$ "orta" düzeydedir. Öğretmen algılarına göre okul yöneticileri yasal gücü $(\bar{x}=4,06)$ "yüksek" düzeyde, ödül gücünü $(\bar{x}=3,60)$ "yüksek" düzeyde, zorlayıcı gücü $(\bar{x}=2,50)$ "düşük" düzeyde, karizmatik gücü ve uzmanlık gücünü $(\bar{x}=3,75)$ "yüksek" düzeyde kullanmaktadırlar. Bulgulara bakarak, okul yöneticilerinin zorlayıcı güç dışındaki diğer güç türlerini yüksek düzeyde kullandıkları söylenebilir. Öğretmenlerin algılarına göre yöneticiler en çok uzmanlık ve karizmatik güç türünü sonra sırasıyla yasal, ödül ve zorlayıcı güç türlerini kullanmaktadırlar.

3.2. Öğretmenlerin Örgütsel Vatandaşlık Algıları ve Yöneticilerinin Güç Kullanım Düzeylerinin Cinsiyet ve Son Çalıştığı Okuldaki Hizmet Süresine Göre Bulguları

\subsubsection{Cinsiyet Değişkenine İlişkin Bulgular}

Öğretmenlerin örgütsel vatandaşlık algıları ile yöneticilerinin güç kullanım algılarının cinsiyet değişkenine göre farklılık gösterip göstermediğine ilişkin $t$ testi yapılmıştır ve bulgular Tablo 5'de verilmiştir. 
Tablo 5. Cinsiyet Değişkenine Göre Öğretmen Örgütsel Vatandaşlık Davranışı ve Yönetici Güç Tipi Algısı ve Bunların Alt Boyutlarına İlişkin Aritmetik Ortalama ve t Testi Sonuçları

\begin{tabular}{|c|c|c|c|c|c|c|c|}
\hline & Cinsiyet & $\mathbf{N}$ & $\bar{x}$ & SS & sd & $\mathbf{t}$ & $\mathbf{p}$ \\
\hline \multirow{2}{*}{ Örgütsel Vatandaşlık } & Kadın & 124 & 3,67 &, 33 & \multirow[t]{2}{*}{210} & \multirow[t]{2}{*}{,342 } & \multirow[t]{2}{*}{, 732} \\
\hline & Erkek & 88 & 3,65 &, 34 & & & \\
\hline \multirow{2}{*}{ Yardımlaşma } & Kadın & 124 & 4,12 &, 57 & \multirow[t]{2}{*}{210} & \multirow[t]{2}{*}{,- 007} & \multirow[t]{2}{*}{,994 } \\
\hline & Erkek & 88 & 4,12 &, 57 & & & \\
\hline \multirow{2}{*}{ Centilmenlik } & Kadın & 124 & 4,22 &, 82 & \multirow[t]{2}{*}{210} & \multirow[t]{2}{*}{, 850} & \multirow[t]{2}{*}{, 414} \\
\hline & Erkek & 88 & 4,14 & ,66 & & & \\
\hline \multirow{2}{*}{ Vicdanlılık } & $\overline{\text { Kadın }}$ & 124 & 4,37 &, 53 & \multirow[t]{2}{*}{210} & \multirow[t]{2}{*}{1,599} & \multirow[t]{2}{*}{, 102} \\
\hline & Erkek & 88 & 4,24 & ,62 & & & \\
\hline \multirow{2}{*}{ Sivil Erdem } & Kadın & 124 & 3,96 & ,63 & \multirow[t]{2}{*}{210} & \multirow[t]{2}{*}{,456 } & \multirow[t]{2}{*}{, 657} \\
\hline & Erkek & 88 & 3,92 &, 55 & & & \\
\hline \multirow{2}{*}{ Güç } & Kadın & 124 & 3,45 &, 47 & \multirow[t]{2}{*}{210} & \multirow[t]{2}{*}{2,958} & \multirow[t]{2}{*}{, $003^{*}$} \\
\hline & Erkek & 88 & 3,25 &, 49 & & & \\
\hline \multirow{2}{*}{ Yasal } & Kadın & 124 & 4,08 & 65 & \multirow[t]{2}{*}{210} & \multirow[t]{2}{*}{, 380} & \multirow[t]{2}{*}{,693 } \\
\hline & Erkek & 88 & 4,04 &, 82 & & & \\
\hline \multirow{2}{*}{ Ödül } & Kadın & 124 & 3,71 &, 86 & \multirow[t]{2}{*}{210} & \multirow[t]{2}{*}{2,235} & \multirow[t]{2}{*}{, $029^{*}$} \\
\hline & Erkek & 88 & 3,45 &, 79 & & & \\
\hline \multirow{2}{*}{ Zorlayıcı } & Kadın & 124 & 2,49 &, 89 & \multirow[t]{2}{*}{210} &,- 030 & ,976 \\
\hline & Erkek & 88 & 2,50 & ,96 & & & \\
\hline Uzmanlık & $\overline{\text { Kadın }}$ & 124 & 3,85 & ,84 & 210 & 1,780 & ,069 \\
\hline UZПпаПIIK & Erkek & 88 & 3,62 & ,97 & & & \\
\hline Karizmatik & $\overline{\text { Kadın }}$ & 124 & 3,68 & 1,04 & 210 & 3,057 &, $002^{*}$ \\
\hline NanzTHatik & Erkek & 88 & 3,22 & 1,11 & & & \\
\hline
\end{tabular}

Tablo 5'de görüldügü gibi öğretmenlerin örgütsel vatandaşlık davranışları ve bunların alt boyutlarına ilişkin cinsiyet değişkenine göre yapılan t testinde anlamlı bir farklılaşma görülmemiştir. Ortalamalara bakıldığında örgütsel vatandaşlık ve alt boyutlarına dair kadın öğretmen ve erkek öğretmenlerde algılama benzerlikleri olduğu görülmektedir.

Öğretmenlerin yöneticilerdeki güç algılarının cinsiyet değişkenine göre değişip değişmediğini test etmek için yapılan t-testinden yararlanılmıştır. Analiz sonuçları kadın öğretmenler lehine anlamlı bir fark olduğunu göstermektedir $(\mathrm{t}=2,958, \mathrm{p}<.05)$. Kadın öğretmenler yöneticilerdeki gücü erkek öğretmenlere göre daha fazla algilamaktadırlar. Öğretmenlerin yöneticilerdeki güç algılarının alt boyutlarının cinsiyete değişkenine göre değişip değişmediğini test etmek için yapılan $t$ testinde ödül gücünde $(t=2,235, p<.05)$ ve karizmatik güç türünde $(\mathrm{t}=3,057, \mathrm{p}<.05)$ kadın öğretmenler lehine anlamlı bir farklılaşma görülmüştür.

\subsubsection{Son Çalış̧tğı Okuldaki Hizmet Süresi Değişkenine İliş̧in Bulgular}

Öğretmenlerin örgütsel vatandaşlık algıları ile yöneticilerinin güç kullanım algılarının son çalıştığı okuldaki hizmet süresi değişkenine göre farklılık gösterip göstermediğine ilişkin ANOVA testi yapılmıştır ve bulgular Tablo 6'da verilmiştir. 
Tablo 6. Son Çalıştığı Okuldaki Hizmet Süresi Değişkenine Göre Öğretmen Örgütsel Vatandaşlık Davranışı ve Yönetici Güç Tipi Algısı ve Bunların Alt Boyutlarına İlişkin Aritmetik Ortalama ve ANOVA Sonuçları

\begin{tabular}{|c|c|c|c|c|c|c|c|c|c|}
\hline Değișken & Hizmet süresi & $\mathbf{N}$ & $\bar{x}$ & SS & & KT & SD & $\mathbf{F}$ & $\mathbf{P}$ \\
\hline \multirow{4}{*}{$\begin{array}{l}\text { Örgütsel } \\
\text { Vatandaşlık }\end{array}$} & $1 \mathrm{y} 1 \mathrm{l}$ & 77 & 3,67 &, 36 & Gruplar arası & ,008 & 2 & ,035 & ,966 \\
\hline & $2-4$ yil & 91 & 3,66 & ,29 & Grupla içi & 23,188 & 206 & & \\
\hline & 5 yıl ve üzeri & 41 & 3,67 & ,37 & Toplam & 23,196 & 208 & & \\
\hline & Toplam & 209 & 3,66 & ,33 & & & & & \\
\hline \multirow{4}{*}{ Yardımlaşma } & $1 \mathrm{y} 1 \mathrm{l}$ & 77 & 4,10 & ,67 & Gruplar arası &, 053 & 2 & ,081 & ,922 \\
\hline & $2-4$ y1l & 91 & 4,13 & ,45 & Grupla içi & 67,620 & 206 & & \\
\hline & 5 yıl ve üzeri & 41 & 4,10 & ,60 & Toplam & 67,673 & 208 & & \\
\hline & Toplam & 209 & 4,12 &, 57 & & & & & \\
\hline \multirow{4}{*}{ Centilmenlik } & $1 \mathrm{y} 1 \mathrm{l}$ & 77 & 4,21 & ,79 & Gruplar arası &, 687 & 2 & ,592 &, 554 \\
\hline & $2-4$ y1l & 91 & 4,21 & ,69 & Grupla içi & 119,500 & 206 & & \\
\hline & 5 yıl ve üzeri & 41 & 4,07 &, 85 & Toplam & 120,187 & 208 & & \\
\hline & Toplam & 209 & 4,18 & ,76 & & & & & \\
\hline \multirow{4}{*}{ Vicdanlılık } & $1 \mathrm{y} 1 \mathrm{l}$ & 77 & 4,36 &, 58 & Gruplar arası & ,204 & 2 & ,307 &, 736 \\
\hline & $2-4$ y1l & 91 & 4,29 &, 55 & Grupla içi & 68,442 & 206 & & \\
\hline & 5 yıl ve üzeri & 41 & 4,31 & ,62 & Toplam & 68,647 & 208 & & \\
\hline & Toplam & 209 & 4,32 &, 57 & & & & & \\
\hline \multirow{4}{*}{ Sivil Erdem } & $1 \mathrm{y} 1 \mathrm{l}$ & 77 & 3,98 & ,61 & Gruplar arası &, 161 & 2 & ,222 &, 801 \\
\hline & $2-4$ y1l & 91 & 3,93 &, 57 & Grupla içi & 74,457 & 206 & & \\
\hline & 5 yıl ve üzeri & 41 & 3,90 & ,64 & Toplam & 74,617 & 208 & & \\
\hline & Toplam & 209 & 3,94 &, 59 & & & & & \\
\hline \multirow{4}{*}{ Güç } & $1 \mathrm{y} 1 \mathrm{l}$ & 77 & 3,37 & ,49 & Gruplar arası & ,418 & 2 & ,859 & ,425 \\
\hline & $2-4$ y1l & 91 & 3,39 &, 50 & Grupla içi & 50,071 & 206 & & \\
\hline & 5 yil ve üzeri & 41 & 3,27 & ,46 & Toplam & 50,489 & 208 & & \\
\hline & Toplam & 209 & 3,35 & ,49 & & & & & \\
\hline \multirow{4}{*}{ Yasal } & $1 \mathrm{y} 1 \mathrm{l}$ & 77 & 4,13 & ,71 & Gruplar arası &, 779 & 2 & ,750 & ,474 \\
\hline & $2-4$ y1l & 91 & 4,04 &, 74 & Grupla içi & 107,005 & 206 & & \\
\hline & 5 yıl ve üzeri & 41 & 3,97 & ,68 & Toplam & 107,785 & 208 & & \\
\hline & Toplam & 209 & 4,06 &, 72 & & & & & \\
\hline \multirow{4}{*}{ Ödül } & 1 y1l & 77 & 3,64 & ,82 & Gruplar aras1 & 2,266 & 2 & 1,627 & ,199 \\
\hline & $2-4$ y1l & 91 & 3,65 & ,82 & Grupla içi & 143,444 & 206 & & \\
\hline & 5 yıl ve üzeri & 41 & 3,38 & ,88 & Toplam & 145,710 & 208 & & \\
\hline & Toplam & 209 & 3,59 &, 84 & & & & & \\
\hline \multirow{4}{*}{ Zorlayıcı } & $1 \mathrm{y} 1 \mathrm{l}$ & 77 & 2,41 & ,95 & Gruplar arası & 3,017 & 2 & 1,777 &, 172 \\
\hline & $2-4$ y1l & 91 & 2,49 & ,89 & Grupla içi & 174,852 & 206 & & \\
\hline & 5 yil ve üzeri & 41 & 2,74 & ,92 & Toplam & 177,869 & 208 & & \\
\hline & Toplam & 209 & 2,51 & ,92 & & & & & \\
\hline \multirow{4}{*}{ Uzmanlık } & $1 \mathrm{y} 1 \mathrm{l}$ & 77 & 3,79 & ,92 & Gruplar arası & 1,633 & 2 & ,996 & ,371 \\
\hline & $2-4$ y1l & 91 & 3,78 & ,91 & Grupla içi & 168,800 & 206 & & \\
\hline & 5 yıl ve üzeri & 41 & 3,57 &, 85 & Toplam & 170,433 & 208 & & \\
\hline & Toplam & 209 & 3,74 & ,91 & & & & & \\
\hline \multirow{4}{*}{ Karizmatik } & $1 \mathrm{y} 1 \mathrm{l}$ & 77 & 3,52 & 1,10 & Gruplar arası & 4,566 & 2 & 1,926 &, 148 \\
\hline & $2-4$ y1l & 91 & 3,57 & 1,06 & Grupla içi & 244,119 & 206 & & \\
\hline & 5 yıl ve üzeri & 41 & 3,18 & 1,12 & Toplam & 248,684 & 208 & & \\
\hline & Toplam & 209 & 3,48 & 1,09 & & & & & \\
\hline
\end{tabular}

Öğretmenlerin örgütsel vatandaşlık davranışlarına ilişkin algılarının son çalıştığı okuldaki hizmet süresine göre değişip değişmediğini test etmek için yapılan ANOVA testinde gruplar arasında anlamlı bir farklılaşma görülmemiştir. Alt boyut karşılaştırmalarına bakıldığında ise, 
yardımlaşma, centilmenlik, vicdanlılık, sivil erdem davranışlarında da öğretmenlerin son çalıştı̆̆ 1 okuldaki hizmet süresine göre anlamlı bir değişme görülmemektedir (Tablo 6). Alt boyut karşılaştırmalarına bakıldığında yasal güç, zorlayıcı güç, ödül gücü, uzmanlık gücü ve karizmatik güç algılarında da öğretmenlerin son çalıştığı okuldaki hizmet süresine göre anlamlı bir değişim görülmemektedir.

\section{3. Öğretmenlerin Örgütsel Vatandaşlık Davranışları Algıları ile Yöneticilerinin} Güç Kullanım Düzeyleri Arasındaki İlişkiye İlişkin Bulgular

Araştırmanın üçüncü alt problemi olan, "Öğretmenlerin örgütsel vatandaşlık davranışları algıları ile yöneticilerinin güç kullanım düzeyleri arasındaki ilişki nasıldır?" sorusuna ilişkin öğretmenlerin örgütsel vatandaşlık davranışları ile yöneticilerin güç kullanım düzeyleri arasındaki ilişkiyi ölçmek amacıyla basit regresyon analizi yapılmıştır (Tablo 7).

Tablo 7. Yönetici Güç Kullanımı ile Örgütsel Vatandaşıı Davranışı Arasındaki İlişkiyi Gösteren Basit Regresyon Analizi Sonuçları

\begin{tabular}{lllllll}
\hline Model 1 & \multicolumn{7}{l}{ Yordanan Değişken Örgütsel Vatandaşlık } & & \\
\hline Yordayıc1 Değişken & ShB & $\mathrm{B}$ & $\beta$ & $\mathrm{T}$ & $\mathrm{p}$ & $\mathrm{r}$ \\
\hline Sabit &, 159 & 3,360 & & 21,178 &, 000 & \\
\hline Yönetici Güç Kullanımı &, 047 &, 089 &, 131 & 1,195 &, 057 &, 131 \\
\hline $\mathrm{R}=, 131$ & & $\mathrm{R}^{2}=, 017$ & & & \\
\hline $\mathrm{F}=3,666$ & $\mathrm{P}=, 057$ & & \\
\hline
\end{tabular}

Yönetici güç kullanımının öğretmenlerin örgütsel vatandaşlık davranışını yordamasına yönelik regresyon analizi sonuçlarına göre, korelasyon katsayısı incelendiğinde yönetici güç kullanımı ile öğretmenlerin örgütsel vatandaşlık arasında düşük düzeyde olumlu bir ilişki $(\mathrm{r}=, 131)$ olduğu görülmektedir (Tablo 7).

3.4. Yöneticilerin Güç Kullanım Düzeyleri Öğretmenlerin Örgütsel Vatandaşlık Davranışlarını Açıklama Düzeyine İlişkin Bulgular

\subsubsection{Yöneticilerin Güç Kullanımının Alt Boyutlarının Örgütsel Vatandaşıı Davranışını Açıklama Düzeyi}

Yöneticilerin güç kullanımının alt boyutlarının örgütsel vatandaşlık davranışını açıklama düzeyine ilişkin sonuçlar Tablo 8'de verilmiştir.

Tablo 8. Örgütsel Vatandaşlık Davranışını Yordamasına İlişkin Çoklu Regresyon Analizi Sonuçları

\begin{tabular}{|c|c|c|c|c|c|c|c|}
\hline \multicolumn{8}{|c|}{ Yordanan Değişken: Örgütsel Vatandaşlık } \\
\hline Yordayıcı Değişken & $\mathrm{B}$ & $\mathrm{ShB}$ & $\beta$ & $\mathrm{t}$ & $\mathrm{p}$ & İkili r & Kismi r \\
\hline Sabit & 3,248 & , 188 & & 17,275 & 000 & & \\
\hline Yasal & ,067 &, 035 & 145 & 1,952 & 052 &, 170 &, 135 \\
\hline Ödül & ,097 & ,043 & ,244 & 2,257 &, 025 & , 184 &, 155 \\
\hline Zorlayıc1 &,- 037 & ,029 &,- 101 & $-1,268$ & ,206 &,- 125 &,- 088 \\
\hline Uzmanlık &, 040 &, 051 &, 107 &, 778 & ,437 &, 170 &, 054 \\
\hline Karizmatik &,- 077 &, 041 &,- 251 & $-1,874$ &, 062 &, 084 &,- 129 \\
\hline $\mathrm{R}=0,281$ & $\mathrm{R}^{2}=0,079$ & & & & & & \\
\hline $\mathrm{F}=3,546$ & $\mathrm{p}=0,004$ & & & & & & \\
\hline
\end{tabular}

Yöneticinin tercih ettiği gücün alt boyutlarının örgütsel vatandaşlık davranışlarını yordamasına ilişkin analiz sonuçlarına bakıldığında; yordayıcı değişkenler yasal güç, ödül gücü, zorlayıcı güç, uzmanlık gücü, karizmatik güç olan gücün boyutları ile yordanan değişken olan örgütsel vatandaşlık davranışı arasında ikili ve kısmi korelasyonlara göre 
karizmatik ve zorlayıcı güç türleri hariç diğer güç türleri ile örgütsel vatandaşlık davranışları arasında olumlu bir ilişkinin olduğu görülmektedir. Bunun yanı sıra tüm kısmı ve ikili korelasyon değerlerine bakıldığında örgütsel vatandaşlık davranışı ile yasal güç, ödül gücü, zorlayıcı güç, uzmanlık gücü ve karizmatik güç arasında düşük düzeyde ilişki bulunmaktadır.

Yöneticinin kullandığı güç tipi örgütsel vatandaşlık davranışı ile düşük düzeyde anlamlı bir ilişki vermektedir $\left(\mathrm{r}=0,281, \mathrm{r}^{2}=0,079, \mathrm{p}<.05\right)$. Yöneticinin kullandığ yasal güç, ödül gücü, zorlayıcı güç, uzmanlık gücü, karizmatik güç boyutları birlikte, örgütsel vatandaşlık davranışındaki toplam varyansın \% 8'ini açıklamaktadır.

Standardize edilmiş regresyon katsayısına $(\beta)$ göre, yordayıcı değişkenlerin örgütsel vatandaşlık davranışları üzerindeki göreli önem sırası; karizmatik, ödül, yasal, uzmanlık ve zorlayıcı güç şeklindedir.

\subsubsection{Yöneticilerin Güç Kullanımının Alt Boyutlarının Örgütsel Vatandaşlık Davranışını Yardımseverlik Alt Boyutunu Açıklama Düzeyi}

Yöneticilerin güç kullanımının alt boyutlarının örgütsel vatandaşlık davranışını yardımseverlik alt boyutunu açıklama düzeyine ilişkin bulgular Tablo 9'da verilmiştir.

Tablo 9. Yardımseverlik Alt Boyutunu Yordamasına İlişkin Çoklu Regresyon Analizi Sonuçları

\begin{tabular}{|c|c|c|c|c|c|c|c|}
\hline \multicolumn{8}{|c|}{ Yordanan Değişken: Yardımseverlik } \\
\hline Yordayıc1 Değișken & B & ShB & $\beta$ & $\mathrm{t}$ & $\mathrm{p}$ & İkili r & Kismi r \\
\hline Sabit & 3,893 &, 307 & & 12,676 &, 000 & & \\
\hline Yasal & ,063 & 056 & ,080 & 1,120 & ,264 & 101 &, 078 \\
\hline Ödül & 228 & ,070 & ,336 & 3,240 & 001 & 238 & 220 \\
\hline Zorlayıcı &,- 168 & 047 &,- 273 & $-3,559$ & 000 &,- 270 &,- 241 \\
\hline Uzmanlık &, 085 & 084 &, 135 & 1,017 & 310 & 197 & ,071 \\
\hline Karizmatik &,- 216 & 067 &,- 415 & $-3,219$ & 001 & 094 &,- 219 \\
\hline $\mathrm{R}=, 387$ & $\mathrm{R}^{2}=, 149$ & & & & & & \\
\hline$F=7,240$ & $\mathrm{p}=, 000$ & & & & & & \\
\hline
\end{tabular}

Yöneticinin tercih ettiği güç türünün alt boyutlarının örgütsel vatandaşlık davranışının yardımseverlik alt boyutunu yordamasına ilişkin analiz sonuçlarına bakıldığında; ikili ve kısmi korelasyonlara göre karizmatik ve zorlayıcı güç türleri hariç diğer güç türleri ile örgütsel vatandaşlık davranışının yardımseverlik alt boyutu arasında olumlu bir ilişkinin olduğu, bunun yanı sıra tüm güç türleri ile örgütsel vatandaşlık davranışının yardımseverlik alt boyutu arasında düşük düzeyde bir ilişki olduğu gözlenmektedir. Kısmı ve ikili korelasyon değerlerine bakıldığında; örgütsel vatandaşlık davranışının yardımseverlik alt boyutu ile yasal güç, ödül gücü, zorlayıcı güç, uzmanlık gücü ve karizmatik güç arasında düşük düzeyde ilişki bulunmaktadır. Güç türleri ile örgütsel vatandaşlık davranışının yardımseverlik alt boyutu arasındaki en yüksek ilişkinin zorlayıcı güç türü ile yardımseverlik arasında olduğu görülmektedir $(\mathrm{r}=0,27)$.

Yöneticinin kullandığı yasal, ödül, zorlayıcı, uzmanlık, karizmatik güç tipi örgütsel vatandaşlık davranışının yardımseverlik alt boyutu ile orta düzeyde anlamlı bir ilişki vermektedir $\left(r=0,387, r^{2}=0,149, p<.05\right)$. Yöneticinin kullandiğ 1 yasal güç, ödül gücü, zorlayıcı güç, uzmanlık gücü, karizmatik güç boyutları birlikte, örgütsel vatandaşlık davranışının yardımseverlik alt boyutundaki toplam varyansın \% 14,9'unu açıklamaktadır.

Tablo 9'daki standardize edilmiş regresyon kat sayısına $(\beta)$ göre, yordayıcı değişkenlerin örgütsel vatandaşlık davranışının yardımseverlik alt boyutu üzerindeki göreli önem sırası; karizmatik, ödül, zorlayıcı, uzmanlık, yasal güç türüdür. 


\subsubsection{Yöneticilerin Güç Kullanımının Alt Boyutlarının Örgütsel Vatandaşlık Davranışının Centilmenlik Alt Boyutunu Açıklama Düzeyi}

Yöneticilerin güç kullanımının alt boyutlarının örgütsel vatandaşlık davranışının centilmenlik alt boyutunu açıklama düzeyine ilişkin bulgular Tablo 10'da verilmiştir.

Tablo 10. Centilmenlik Alt Boyutunu Yordamasına İlişkin Çoklu Regresyon Analizi Sonuçları

\begin{tabular}{lrrrrrrr}
\hline & \multicolumn{7}{c}{ Yordanan Değişken: Centilmenlik } \\
\hline Yordayıcı Değişken & $\mathrm{B}$ & \multicolumn{1}{c}{ ShB } & \multicolumn{1}{c}{$\beta$} & \multicolumn{1}{c}{$\mathrm{t}$} & $\mathrm{p}$ & İkili r & Kısmi r \\
\hline Sabit & 1,768 &, 416 & & 4,247 &, 000 & & \\
Yasal &,- 035 &, 076 &,- 033 &,- 462 &, 645 &,- 050 &,- 032 \\
Ödül &,- 120 &, 095 &,- 133 & $-1,258$ &, 210 &,- 220 &,- 087 \\
Zorlayıc1 &, 237 &, 064 &, 289 & 3,710 &, 000 &, 322 &, 250 \\
Uzmanlık &,- 088 &, 113 &,- 105 &,- 778 &, 437 &,- 235 &,- 054 \\
Karizmatik &, 102 &, 091 &, 147 & 1,121 &, 263 &,- 187 &, 078 \\
\hline $\mathrm{R}=, 348$ & $\mathrm{R}^{2}=, 121$ & & & & & \\
$\mathrm{~F}=5,677$ & $\mathrm{p}=, 000$ & & & & & & \\
\hline
\end{tabular}

Yöneticinin tercih ettiği güç tipinin alt boyutlarının örgütsel vatandaşlık davranışının centilmenlik alt boyutunu yordamasına ilişkin analiz sonuçlarına bakıldığında, yordayıcı gücün boyutları yordanan değişken olan örgütsel vatandaşlık davranışının centilmenlik alt boyutu arasında ikili ve kısmi korelasyonlara göre; karizmatik ve zorlayıcı güç türleri hariç diğer güç türleri ile örgütsel vatandaşlık davranışının centilmenlik alt boyutu arasında ters bir ilişkinin olduğu, bunun yanı sıra zorlayıcı güç ile centilmenlik arasında orta düzeyde bir ilişki olduğu $(\mathrm{r}=0,322)$, diğer güç türleri ile örgütsel vatandaşlık davranışları arasında düşük düzeyde bir ilişki olduğu gözlenmektedir. Yöneticinin kullandığı güç tipi ile örgütsel vatandaşlık davranışının centilmenlik alt boyutu arasındaki en yüksek ilişkinin ikili korelasyonlara bakıldığında zorlayıcı güç türü ile centilmenlik arasında olduğu görülmektedir $(\mathrm{r}=0,322)$. Diğer boyutlar çıkarıldığında kısmi korelasyon değerine bakıldığında, örgütsel vatandaşlık davranışının centilmenlik alt boyutu ile zorlayıcı güç arasında düşük düzeyde ilişki bulunmaktadır $(\mathrm{r}=0,255)$.

Yöneticinin güç tipi tercihi (yasal, ödül, zorlayıcı, uzmanlık, karizmatik) örgütsel vatandaşlık davranışının centilmenlik alt boyutu ile orta düzeyde anlamlı bir ilişki vermektedir $\left(r=0,348, r^{2}=0,121, p<.05\right)$. Yöneticinin kullandığı yasal güç, ödül gücü, zorlayıcı güç, uzmanlık gücü, karizmatik güç tercihleri birlikte, örgütsel vatandaşlık davranışının centilmenlik alt boyutundaki toplam varyansın \% 12,1'ini açıklayabilmektedir.

Standardize edilmiş regresyon katsayısına ( $\beta$ ) göre (Tablo 10), yordayıcı değişkenlerin örgütsel vatandaşlık davranışının centilmenlik alt boyutu üzerindeki göreli önem sırası; zorlayıcı, karizmatik, ödül, uzmanlık, yasal güç türüdür.

\subsubsection{Yöneticilerin Güç Kullanımının Alt Boyutlarının Örgütsel Vatandaşlık Davranışının Vicdanlılık Alt Boyutunu Açıklama Düzeyi}

Yöneticilerin güç kullanımının alt boyutlarının örgütsel vatandaşlık davranışının vicdanlılık alt boyutunu açıklama düzeyine ilişkin bulgular Tablo 11'de verilmiştir. 
Tablo 11. Vicdanlılık Alt Boyutunu Yordamasına İlişkin Çoklu Regresyon Analizi Sonuçları

\begin{tabular}{|c|c|c|c|c|c|c|c|}
\hline \multicolumn{8}{|c|}{ Yordanan Değişken: Vicdanlılık } \\
\hline Yordayıcı Değişken & B & ShB & $\beta$ & $\mathrm{t}$ & $\mathrm{p}$ & İkili r & Kismi r \\
\hline Sabit & 3,455 & 317 & & 10,908 & 000 & & \\
\hline Yasal & ,221 & 058 & 277 & 3,795 & 000 & 298 & 256 \\
\hline Ödül & -,023 & 073 &,- 034 &,- 322 & 748 & 084 &,- 022 \\
\hline Zorlayıcı &,- 060 & ,049 &,- 096 & $-1,229$ & 220 &,- 110 &,- 085 \\
\hline Uzmanlık & 067 & ,086 & ,106 &, 782 & 435 & ,185 &, 054 \\
\hline Karizmatik &,- 014 & ,069 &,- 027 &,- 207 & 836 & 104 &,- 014 \\
\hline $\mathrm{R}=, 328$ & $\mathrm{R}^{2}=, 107$ & & & & & & \\
\hline $\mathrm{F}=4,954$ & $\mathrm{p}=, 000$ & & & & & & \\
\hline
\end{tabular}

Yöneticinin tercih ettiği güç tipinin örgütsel vatandaşlık davranışının vicdanlılık alt boyutunu yordamasına ilişkin analiz sonuçlarına bakıldığında, yordayıcı gücün boyutları yordanan değişken olan örgütsel vatandaşlık davranışının vicdanlılık alt boyutu arasında ikili ve kısmi korelasyonlara göre ödül, karizmatik ve zorlayıcı güç türleri ile örgütsel vatandaşlık davranışının vicdanlılık alt boyutu arasında ters bir ilişkinin olduğu, bunun yanı sıra tüm güç türleri ile örgütsel vatandaşlık davranışları arasında düşük düzeyde bir ilişki olduğu gözlenmektedir. Kısmı ve ikili korelasyon değerlerine bakıldığında, örgütsel vatandaşlık davranışının vicdanlılık alt boyutu ile yasal güç, ödül gücü, zorlayıcı güç, uzmanlık gücü ve karizmatik güç arasında düşük düzeyde ilişki bulunmaktadır. Yöneticinin kullandığı güç türü ile örgütsel vatandaşlık davranışının vicdanlılık alt boyutu arasındaki en yüksek ilişki yasal güç türü ile vicdanlılık arasında olduğu görülmektedir $(\mathrm{r}=0,298)$.

Yöneticinin güç tipi tercihinin örgütsel vatandaşlık davranışının vicdanlılık alt boyutu ile orta düzeyde anlamlı bir ilişki vermektedir $\left(r=0,328, r^{2}=0,107, p<.05\right)$. Yöneticinin kullandığı yasal güç, ödül gücü, zorlayıcı güç, uzmanlık gücü, karizmatik güç tercihleri birlikte, örgütsel vatandaşlık davranışının vicdanlılık alt boyutundaki toplam varyansın \% 10,7'sini açıklayabilmektedir.

Standardize edilmiş regresyon katsayısına $(\beta)$ göre (Tablo 11), yordayıcı değişkenlerin örgütsel vatandaşlık davranışının centilmenlik alt boyutu üzerindeki göreli önem sırası; yasal, uzmanlık, zorlayıcı, ödül, karizmatik güç şeklindedir.

\subsubsection{Yöneticilerin Güç Kullanımının Alt Boyutlarının Örgütsel Vatandaşlık Davranışının Sivil Erdem Alt Boyutunu Açıklama Düzeyi}

Yöneticilerin güç kullanımının alt boyutlarının örgütsel vatandaşlık davranışının sivil erdem alt boyutunu açıklama düzeyine ilişkin bulgular Tablo 12'de verilmiştir.

Tablo 12. Sivil Erdem Alt Boyutunu Yordamasına İlişkin Çoklu Regresyon Analizi Sonuçları

\begin{tabular}{|c|c|c|c|c|c|c|c|}
\hline \multicolumn{8}{|c|}{ Yordanan Değişken: Sivil Erdem } \\
\hline Yordayıı Değişken & $\mathrm{B}$ & ShB & $\beta$ & $\mathrm{t}$ & $\mathrm{p}$ & İkili r & Kismi r \\
\hline Sabit & 3,230 & ,337 & & 9,579 & 000 & & \\
\hline Yasal & ,025 & ,062 & ,030 & ,405 & 686 & ,063 & ,028 \\
\hline Ödül & ,174 & 077 & 243 & 2,246 & ,026 & 260 & , 155 \\
\hline Zorlayıc1 &,- 025 & ,052 &,- 038 &,- 475 & 635 &,- 139 &,- 033 \\
\hline Uzmanlık &, 050 & ,092 & 075 &, 543 & ,587 & 220 & 038 \\
\hline Karizmatik &,- 041 & ,074 &,- 074 &,- 549 & ,583 & 195 &,- 038 \\
\hline $\mathrm{R}=, 270$ & $\overline{\mathrm{R}^{2}=, 073}$ & & & & & & \\
\hline $\mathrm{F}=3,229$ & $\mathrm{p}=, 008$ & & & & & & \\
\hline
\end{tabular}


Yönetici tarafından tercih edilen güç tipinin örgütsel vatandaşlık davranışının sivil erdem alt boyutunu yordamasına ilişkin analiz sonuçlarına bakıldığında; yordayıcı gücün boyutları olan yasal, ödül, zorlayıcı, uzmanlık, karizmatik güç ile yordanan değişken olan örgütsel vatandaşlık davranışının sivil erdem alt boyutu arasında ikili ve kısmi korelasyonlara göre zorlayıcı güç türü hariç güç türleri ile örgütsel vatandaşlık davranışının sivil erdem alt boyutu arasında olumlu bir ilişkinin olduğu görülmektedir. Bunun yanı sıra tüm güç türleri ile örgütsel vatandaşlık davranışları arasında düşük düzeyde bir ilişki olduğu gözlenmektedir. Kısmı ve ikili korelasyon değerlerine bakıldığında örgütsel vatandaşlık davranışının sivil erdem alt boyutu ile yasal güç, ödül gücü, zorlayıcı güç, uzmanlık gücü ve karizmatik güç arasında düşük düzeyde ilişki bulunmaktadır. Yöneticinin kullandığg güç türü ile örgütsel vatandaşlık davranışının sivil erdem alt boyutu arasındaki en yüksek ilişki ödül gücü ile sivil erdem arasında olduğu görülmektedir $(\mathrm{r}=0,26)$.

Yöneticinin güç tipi tercihinin örgütsel vatandaşlık davranışının sivil erdem alt boyutu ile düşük düzeyde anlamlı bir ilişki vermektedir $\left(r=0,27, r^{2}=0,073, p<.05\right)$. Yöneticinin kullandığı yasal güç, ödül gücü, zorlayıcı güç, uzmanlık gücü, karizmatik güç tercihleri birlikte, örgütsel vatandaşlık davranışının vicdanlılık alt boyutundaki toplam varyansın $\%$ 7,3'ünü açıklayabilmektedir.

Tablo 12'deki, standardize edilmiş regresyon katsayısına $(\beta)$ göre yordayıcı değişkenlerin örgütsel vatandaşlık davranışının sivil erdem alt boyutu üzerindeki göreli önem sırası; ödül, uzmanlık, karizmatik, zorlayıcı, yasal güç şeklindedir.

\section{SONUÇ VE TARTIŞMA}

\section{1. Öğretmenlerin Örgütsel Vatandaşık Algıları ile Yöneticilerin Güç Kullanım Düzeylerine İliş̧kin Sonuç ve Tartışma}

Öğretmenlerin genel olarak örgütsel vatandaşlık davranışları algıları yüksek düzeydedir. Alan yazında da öğretmenlerin örgütsel vatandaşlık davranışlarının yüksek olduğu görülmektedir (Baykal, 2013; Uslu, Balc1 ve Uslu, 2012; Y1lmaz ve Altınkurt, 2012b; Yılmaz, 2012; Şentürk ve Baş, 2011; Oğuz, 2011; Çelik, 2010; Yarım 2009; Titrek, Bayrakç1 ve Zafer, 2009; Polat ve Celep, 2008; Polat, 2007). Buna karşın bazı çalışmalarda da öğretmenleri ÖVD'lara ilişkin algıları orta düzeyde bulunmuştur (Sezgin ve Kılınç, 2012; Gökmen, 2011; Çetin, 2011) ilköğretim öğretmenlerin üzerinde yaptığı çalışmada öğretmenleri ÖVD’lara ilişkin algılarını orta düzeyde bulmuşlardır.

Öğretmenlerin örgütsel vatandaşlık davranışının yardımlaşma, sivil erdem, centilmenlik alt boyutlarına ait algıları yüksek düzeyde iken vicdanlılık alt boyutuna ait algıları oldukça yüksek düzeydedir. Öğretmenler örgütsel vatandaşlık davranışlarından en çok vicdanlılık alt boyutuna yönelik davranışlar sergilemekte olup, sonra sırasıyla yardımlaşma, sivil erdem, centilmenlik alt boyutlarına yönelik davranışlar sergilemektedirler. Baykal (2013) öğretmenlerin örgütsel vatandaşlık davranışlarını en çok sergilediklerinden az sergilediklerine doğru nezaket, vicdanlılık, centilmenlik, özgecilik, sivil erdem davranışları olduğunu bulmuştur. Büyüközkan'ın (2012) bulgularına göre öğretmenler en yüksek örgütsel vatandaşlık davranışını nezaket boyutunda göstermekte sonra sırasıyla vicdanlılık, özgecilik, sivil erdem ve centilmenlik boyutları takip etmektedir. Yapılan her iki çalışmanın sonucunun bu çalışma ile örtüşmediği görülmektedir.

Öğretmenlerin algılarına göre genel olarak okul yöneticileri gücü orta düzeyde kullanmaktadırlar. Yılmaz ve Altınkurt (2012b) bu çalışmanın sonuçlarının aksine ilköğretim okulu öğretmenleri ile yaptığı çalışmada okul yöneticilerinin güç kaynaklarının tamamını yüksek düzeyde kullandıkları sonucuna ulaşmışlardır. 
Öğretmen algılarına göre okul yöneticileri yasal gücü, ödül gücünü, karizmatik gücü ve uzmanlık gücünü yüksek düzeyde kullanmakta iken zorlayıcı gücü düşük düzeyde kullanmaktadırlar. Öğretmenlere göre yöneticiler en çok uzmanlık ve karizmatik güç türünü sonra sırasıyla; yasal, ödül ve zorlayıcı güç türlerini kullanmaktadırlar. Bu durumda okulların otokratik yönetimden tamamen uzaklaşmasa da güç kullanımında uzmanlık ve karizmatik gücün ön plana çıkması yönetim anlayışlarında değişimler olmaya başladığını göstermektedir. Aslanargun (2009) okul yöneticilerinin karizmatik, ödül gücü ve zorlayıcı gücün okul müdürlerinde gösterilme sıklığının az olduğu sonucuna ulaşmıştır. Kayalı (2011) öğretmenlerin görüşlerine göre ödül, uzmanlık ve karizma güç türlerini müdürlerin yüksek düzeyde kullandıklarını bulurken, bu çalışmanın aksine zorlayıcı gücü kullanma düzeylerinin çok düşük, yasal gücü kullanma düzeylerinin orta düzeyde olduğu sonucuna ulaşmıştır. Polat (2010) okul öncesi yöneticileri ile yaptığı çalışmada okul öncesi eğitim yöneticilerinin yönetsel güç türlerinden ödül gücünü, uzmanlık gücünü, bilgi gücünü, karizmatik gücünü kullanma bakımından bu çalışma ile paralel sonuçlara ulaşırken, zorlayıcı gücü kullanma bakımından farklı bir sonuç olarak orta düzeyde kullandıkları sonucuna ulaşmıştır. Sonucun böyle çıkmasında yönetilen okul türünün farklı olmasının etkili olmuş olacağı düşünülmektedir. Zafer'in (2008) ilköğretim okullarında yaptığı araştırmada okul yöneticilerin kullandıkları güç kaynaklarını, bu araştırmadan farklı olarak sırasıyla; yasal, zorlayıc1, uzmanlık, karizma ve ödül gücü olarak belirlenmiştir. Yılmaz ve Altınkurt' un (2012a) ortaöğretim okullarında yaptığ 1 araştırmada okul yöneticilerinin güç kaynaklarının tamamını orta düzeyin üzerinde kullanmakta olduğu ve okul yöneticilerin kullandıkları güç kaynaklarını sırasıyla, yasal gücü, uzmanlık gücü, karizmatik güç, zorlayıcı güç ve ödül gücü olduğu sonucuna ulaşmışlardır. Yine Yılmaz ve Altınkurt (2012b) aynı yıl içerisinde yaptığı çalışmada yöneticilerin gücü kullanma sırasını önceki çalışmasına paralel bulmuştur. Titrek ve Zafer (2009) ilköğretim okullarında yaptıkları çalışmada yöneticilerin güç türlerini yasal güç, zorlayıcı güç, uzmanlık gücü, karizmatik güç ve ödül gücü sırasıyla kullandıklarını belirtmişlerdir. Özaslan ve Gürsel (2008) öğretim elemanlarının algıları ile bölüm başkanlarının en yoğun kullandığı güç tipinin ödüllendirme gücü olduğu sonucuna ulaşmışlardır. Bahsedilen araştırmalardan çıkan sonuçlara ve bu çalışmadan çıkan sonuca bakıldığında öğretmen algılarına göre yöneticilerin kullandığı güç tiplerinin farklılık gösterdiği görülmektedir.

\section{2. Öğretmenlerin Örgütsel Vatandaşlık Algıları ve Yöneticilerinin Güç Kullanım Düzeylerinin Cinsiyet ve Son Çalıştığı Okuldaki Hizmet Süresi Değişkenlerine Göre Sonuçlar ve Tartışma}

Öğretmenlerin örgütsel vatandaşlık davranışları ve bunların alt boyutlarına ilişkin cinsiyet değişkenine göre anlamlı bir farklılaşma görülmemiştir. Örgütsel vatandaşlık ve alt boyutlarına dair ortalamalara göre kadın öğretmen ve erkek öğretmenlerde algılama benzerlikleri olduğu görülmektedir. Baykal (2013), Demirel (2012), Büyüközkan (2012), Bulut (2011), Gök (2010) ve Polat (2007) öğretmenlerin örgütsel vatandaşlık davranışı ile ilgili görüşlerinin cinsiyete göre değiştiği sonucuna ulaşmıştır. Yılmaz ve Altınkurt (2012b), Yılmaz (2012), Çetin (2011), Gökmen (2011), Korkmaz (2011), Yılmaz (2010), Yarım (2009), Öztürk (2009), Özcan (2008) ve Aktay (2008) ise öğretmenlerin örgütsel vatandaşlık davranışı ile ilgili görüşlerinin cinsiyete göre değişmediği sonucuna ulaşmışlardır.

Öğretmenlerin yöneticilerdeki güç algılarında cinsiyete değişkenine göre anlamlı bir farklılaşma görülmektedir ve kadın öğretmenlerin yöneticilerdeki gücü erkek öğretmenlere göre daha fazla algıladığı görülmektedir. Öğretmenlerin yöneticilerdeki güç algılarının alt boyutlarından ödül gücünde ve karizmatik güçte anlamlı bir farklılaşma görülmektedir. Kadın öğretmenler yöneticilerin ödül gücü ve karizmatik gücünü daha sıklıkla gösterdiğini düşünmektedirler. Üstün (2013) yasal güç, zorlayıcı güç, ödül gücü, karizmatik güç ve 
uzmanlık gücü ile cinsiyet arasında; Demirel (2012) ödül gücü ile cinsiyet arasında, Kayalı (2011) karizmatik güç, uzmanlık gücü ve zorlayıcı güç ile cinsiyet arasında; Gökkaya (2010) ve Aslanargun (2009) zorlayıcı güç ile cinsiyet arasında anlamlı farklılıklar bulurken, Zafer (2008) cinsiyet değişkeninin öğretmenlerin örgütsel güç algısında bir etkisinin olmadığı sonucuna ulaşılmıştır. Araştırmalar incelendiğinde bu çalışma ile paralel sonuçlara ulaşan araştırmacılar olduğu görülmektedir (Üstün, 2013; Demirel, 2012).

Öğretmenlerin örgütsel vatandaşlık davranışları algıları son çalıştığı okuldaki hizmet süresine göre değişmemektedir. Örgütsel vatandaşlık davranışının alt boyutları olan yardımlaşma, centilmenlik, vicdanlılık, sivil erdem davranışlarında öğretmenlerin son çalıştığı okuldaki hizmet süresine göre anlamlı bir değişim görülmemektedir. Benzer sonuçlara literatürde de karşılaşılmaktadır (Demirel, 2012; Özcan, 2008). Bunun aksine Baykal (2013) çalışmasında öğretmenlerin okuldaki çalışma sürelerine göre sivil erdem dışında kalan örgütsel vatandaşlık düzeylerinin istatistiksel olarak farklılaştığı belirlemiştir. Aktay (2008) ise ortaöğretimde görev yapan yönetici ve öğretmenlerin örgütsel vatandaşlık okuldaki görev sürelerine göre; gönüllülük, vicdanlılık alt boyutları ile örgütsel vatandaşlık davranışında farklılaşma olduğu sonucuna ulaşmıştır. Bunlar gibi literatürdeki bazı çalışmalarda da son çalıştı̆̆1 okuldaki hizmet süresine göre örgütsel vatandaşlık davranışlarının farklılaştı̆g 1 görülmektedir (Uslu, Balcı ve Uslu, 2012; Uslu, 2011).

Öğretmenlerin yöneticilerde algıladıkları güç son çalıştığı okuldaki hizmet süresine göre değişmemektedir. Gücün alt boyutları olan yasal güç, zorlayıcı güç, ödül gücü, uzmanlık gücü ve karizmatik güçte de öğretmenlerin son çalıştığı okuldaki hizmet süresine göre anlamlı bir değişim görülmemektedir. Benzer sonuçlar alan yazında da mevcut olmasına karşın (Aslanargun, 2009), Üstün (2013) çalışmasında bulunduğu okuldaki görev süresi ile yasal güç, ödül gücü, zorlayıcı güç ile karizmatik güç arasındaki ilişkileri anlamlı bulmazken, görev süresi ile uzmanlık gücü arasındaki ilişkinin anlamlı olduğu sonucuna ulaşmıştır. Buna göre bulunduğu okulda 5 yıldan az görev yapan öğretmenler okul yöneticilerinin uzmanlık gücünü kullandığının farkındadırlar.

\section{3. Öğretmenlerin Örgütsel Vatandaşlık Davranışları Algıları ile Yöneticilerinin Güç Kullanım Düzeyleri Arasındaki İlişsiye İlişkin Sonuç ve Tartışma}

Yönetici güç kullanımı ile öğretmenlerin örgütsel vatandaşlık davranışı arasındaki ilişki için korelasyon katsayısı incelendiğinde yönetici güç kullanımı ile öğretmenlerin örgütsel vatandaşlık davranışı arasında düşük düzeyde olumlu bir ilişki $(r=, 131)$ olduğu görülmektedir. Bu çalışmanın aksine Altınkurt ve Yılmaz (2012b) yöneticilerin kullandıkları güç kaynakları ile öğretmenlerin örgütsel vatandaşlık davranışları arasında orta düzeyde ve anlamlı bir ilişki bulmuştur.

\subsection{Yöneticilerin Güç Kullanım Düzeyleri Öğretmenlerin Örgütsel Vatandaşlık Davranışlarını Açıklama Düzeyine İlişkin Sonuçlar ve Tartışma}

Yöneticinin tercih ettiği güç türünün öğretmenlerin örgütsel vatandaşlık davranışlarını açıklama düzeyleri hakkında şu sonuçlara ulaşılmıştır:

- Yöneticinin kullandığı güç tipi örgütsel vatandaşlık davranışı ile düşük düzeyde anlamlı bir ilişki vermektedir. Yöneticinin kullandığı yasal güç, ödül gücü, zorlayıcı güç, uzmanlık gücü, karizmatik güç boyutları birlikte, örgütsel vatandaşlık davranışındaki toplam varyansın \% 7,9'unu açıklamaktadır.

Yöneticinin kullandığı yasal, ödül, zorlayıcı, uzmanlık, karizmatik güç tipi örgütsel vatandaşlık davranışının yardımseverlik alt boyutu ile orta düzeyde anlamlı bir ilişki vermektedir. Yöneticinin kullandığı güç boyutları birlikte, örgütsel vatandaşlık davranışının yardımseverlik alt boyutundaki toplam varyansın \% 14,9'unu açıklamaktadır. 
- Yöneticinin güç tipi tercihinin (yasal, ödül, zorlayıcı, uzmanlık, karizmatik) örgütsel vatandaşlık davranışının centilmenlik alt boyutu ile orta düzeyde anlamlı bir ilişki vermektedir. Yöneticinin kullandığı yasal güç, ödül gücü, zorlayıcı güç, uzmanlık gücü, karizmatik güç tercihleri birlikte, örgütsel vatandaşlık davranışının centilmenlik alt boyutundaki toplam varyansın \% 12,1'ini açıklayabilmektedir.

Yöneticinin güç tipi tercihinin örgütsel vatandaşlık davranışının vicdanlılık alt boyutu ile orta düzeyde anlamlı bir ilişki vermektedir. Yöneticinin kullandığı yasal güç, ödül gücü, zorlayıcı güç, uzmanlık gücü, karizmatik güç tercihleri birlikte, örgütsel vatandaşlık davranışının vicdanlılık alt boyutundaki toplam varyansın \% 10,7'sini açıklayabilmektedir.

- Yöneticinin güç tipi tercihinin örgütsel vatandaşlık davranışının sivil erdem alt boyutu ile düşük düzeyde anlamlı bir ilişki vermektedir $\left(r=0,27, r^{2}=0,073, p<.05\right)$. Yöneticinin kullandığı yasal güç, ödül gücü, zorlayıcı güç, uzmanlık gücü, karizmatik güç tercihleri birlikte, örgütsel vatandaşlık davranışının vicdanlılık alt boyutundaki toplam varyansin \% 7,3'ünü açıklayabilmektedir.

Sonuçta öğretmenlerin örgütsel vatandaşlık davranışları ve bu davranışların alt boyutları ile yöneticide algıladıkları güç ve güç türleri arasında anlamlı ilişkiler bulunmaktadır. Demirel (2012) çalışmasında öğretmenlerin algılarına göre örgütsel vatandaşlık davranışları ile sırasıyla zorlayıcı güç, ödül gücü, uzmanlık gücü, karizma gücü ve yasal güç arasında anlamlı ilişkiler bulmuştur.

Yılmaz ve Altınkurt (2012b) yöneticilerin kullandıkları güç kaynaklarının, öğretmenlerin örgütsel vatandaşlık davranışlarındaki toplam varyansın yaklaşık beşte birini (\% 20) açıkladığı sonucuna ulaşmışlardır. Bu çalışmada ise yöneticilerin kullandıkları güç kaynakları örgütsel vatandaşlık davranışlarındaki varyansın yaklaşık \% 8'ini açıklamaktadır. Dolayısıyla öğretmenlerin örgütsel vatandaşlık davranışına etki eden etmenlerin \% 92'si okul yöneticilerinin kullandıkları güç kaynakları dışındaki etmenlerdir.

Araştırma sonuçlarına göre şu önerilerde bulunulabilir: Öğretmenleri kaynaştırıcı faaliyetlerin artırılması, okul kültürünün ve ortak değerlerin oluşturulması gerekmektedir. Zümreler arası paylaşımların artırılması yoluna gidilmelidir. Öğretmenlerin sorumlulukları dışındaki işlerde gönüllü olmamalarının nedenlerinin üzerine gidilmelidir. Öğretmenlerin sivil erdem davranışlarında olumsuz davranışların engellenmesi için uzlaştırıcı olunmalı, olay anında konunun üzerine gidilmemeli öncelikle konu üzerinde düşünülmelidir.

\section{KAYNAKÇA}

Açıkalın, Ş. (1993). Öğretmenlerin Okul Müdürlerini Etkileme Güçleri (Ankara İli Örneği). Hacettepe Üniversitesi Ĕ̈itim Fakültesi Dergisi, 9, 183-192.

Aktay, A. (2008). Yönetici ve Öğretmenlerin Değer Tercihleri İle Örgütsel Vatandaşlık Davranışları Arasındaki İlişkinin İncelenmesi. Yayımlanmamış Yüksek Lisans Tezi, Yeditepe Üniversitesi Sosyal Bilimler Enstitüsü, İstanbul.

Aldemir, M. C. (1983). Yöneticilerin Güç Tipleri ile Yabancılaşma ve İş Doyumu Arasındaki İlişkiler. Amme İdaresi Dergisi, 16 (1), 61-77.

Altınkurt, Y. ve Yılmaz, K. (2012b). Okul Yöneticilerinin Kullandığı Güç Kaynakları İle Öğretmenlerin Örgütsel Vatandaşlık Davranışları Arasındaki İlişki. Kuram ve Uygulamada Ĕgitim Bilimleri, 12 (3), 1833-1852.

Altınkurt, Y. ve Yılmaz, K. (2013). Örgütsel Güç Ölçeğinin Geliştirilmesi: Geçerlik ve Güvenirlik Çalışması. e-Uluslararası Eğitim Araştırmaları Dergisi, 4 (4), 1-17. 
Aslanargun, E. (2009). Illköğretim ve Lise Müdürlerinin Okul Yönetimde Kullandı̆̆ Gü̈ç Türleri. Yayımlanmamış Doktora Tezi, Ankara Üniversitesi Eğitim Bilimleri Enstitüsü, Ankara.

Aslanargun, E. (2013). Yönetimde Yeni Yaklaşımlar. Hasan Basri Memduhoğlu ve Kürşat Y1lmaz (Ed.), Örgütlerde Sosyal Güç (s. 175-198). Ankara: Pegem.

Aslanargun, E. ve Eriş, M. ( 2013). Öğretim Elemanlarının Sınıf Yönetiminde Kullandıkları Güç Türleri Ölçeğinin Geliştirilmesi. Atatürk Üniversitesi Sosyal Bilimler Enstitüsü Dergisi, 17 (2), 207-220.

Ay, B. (2007). Öğretmenlerin Öz-Yeterlikleri ve Örgütsel Vatandaşlık Davranışı. Afyon Kocatepe Üniversitesi Sosyal Bilimler Enstitüsü, Afyonkarahisar.

Aydın, M. (2013). Eğitimde Örgütsel Davranış. Ankara: Gazi.

Bağcı, Z. ve Bursalı, M. Y. (2011). Yöneticilerin Güç Kaynaklarının Çalışanların Örgüte Bağlılıkları Üzerine Etkisi: Çalışanların Algılamalarına Bağımlı Analitik Bir İnceleme. Pamukkale Üniversitesi Sosyal Bilimler Enstitüsü Dergisi, 9, 9-21.

Bakan İ. ve Büyükmeşe, T. (2010). Liderlik “Türleri” ve “Güç Kaynakları”na İlişkin MevcutGelecek Durum Karşılaştırması: Eğitim Kurumu Yöneticilerinin Algılarına Dayalı Bir Alan Araştırması. KMÜ Sosyal ve Ekonomik Araştırmalar Dergisi, 12 (19), 73-84.

Balc1, A. (2005). Sosyal Bilimlerde Araştırma: Yöntem, Teknik ve İlkeler. Ankara: Pegem A.

Baykal, K. Ö. (2013). Okul İklimi İle Öğretmenlerin Örgütsel Vatandaşlık Davranışı Arasındaki İlişki Üzerine Bir Araştırma. Yayımlanmamış Yüksek Lisans Tezi, Yeditepe Üniversitesi Sosyal Bilimler Enstitüsü, İstanbul.

Bayrak, S. (2001). Yönetimde Bir İhmal Konusu Olarak Güç ve Güç Yönetimi II. Süleyman Demirel Üniversitesi İktisadi ve İdari Bilimler Fakültesi Dergisi, 6 (1), 23-42.

Bulut, M, Ş. (2011). Ilköğretim Okullarındaki Performans Yönetimi Uygulamaları İle Örgütsel Vatandaşlık Davranışı Arasındaki İlişki. Yayımlanmamış Yüksek Lisans Tezi, Sakarya Üniversitesi Sosyal Bilimler Enstitüsü, Sakarya.

Büyüközkan, A. S. (2012). Öğretmenlerin Örgütsel Yurttaşlı Davranışları İle Tükenmişlikleri Arasındaki İlişkinin Incelenmesi. Yayımlanmamış Yüksek Lisans Tezi, Mersin Üniversitesi Eğitim Bilimleri Enstitüsü, Mersin.

Büyüköztürk, Ş., Çakmak, E.K., Akgün, K.Ş. ve Demirel, F. (2012). Bilimsel Araştırma Yöntemleri. (12. Basım). Ankara: Pegem.

Cohen, L., Manion, L. ve Morrison, K. (2005). Research Methods In Education. (5.Ed.). London: RoutledgeFalmer.

Çelik, M. (2010). Öğretmen Görüşlerine Göre Okul Yöneticilerinin Öğretimsel Liderlik Davranışı İe Öğretmenlerin Örgütsel Vatandaşlık Davranışlarının Analizi. Yayımlanmamış Yüksek Lisans Tezi, Selçuk Üniversitesi Eğitim Bilimleri Enstitüsü, Konya.

Çepni, Z. (2010). Yapısal Eşitlik Modellemesi. yunus.hacettepe.edu.tr/ cepni /mersinsemsunu.ppt adresinden 06.05. 2014 tarihinde alınmıştır.

Çetin, Ş. (2011). Okul Müdürlerinin Liderliği İle Müdür-Öğretmen İlişkisinin Öğretmenlerin Örgütsel Vatandaşlık Davranışı Üzerindeki Etkisi. Yayımlanmamış Doktora Tezi, Gazi Üniversitesi Eğitim Bilimleri Enstitüsü, Ankara. 
Demirel, Ö. G. (2012). Okul Müdürlerinin Güç Kaynaklarını Kullanma Stilleri ve Müdür Desteğinin Kurumsal Vatandaşlık Davranışıyla İlişkisi (Ankara İli Örneği). Yayımlanmamış Yüksek Lisans Tezi, Gazi Üniversitesi Eğitim Bilimleri Enstitüsü, Ankara.

Erdoğan, B. (1997). Örgütsel Güç ve Politika. Yönetim, 26, 21-31.

Gök, Ç. E. B. (2010). Okul Yöneticilerinin Liderlik Stiline İlişkin Öğretmen Algılarının Örgütsel Vatandaşlık Davranışlarına Etkisi. Yayımlanmamış Yüksek Lisans Tezi, Akdeniz Üniversitesi Sosyal Bilimler Enstitüsü, Antalya.

Gökkaya, F. (2010). Lider Güç Türlerinin Örgütsel Öğrenme Üzerine Etkileri (Aydın Köşk ve Germencik Illköğretim Okulları Örneği). Yayımlanmamış Yüksek Lisans Tezi, Beykent Üniversitesi Sosyal Bilimler Enstitüsü, İstanbul.

Gökmen, A. (2011). Illköğretim Öğretmenlerinin Örgütsel Vatandaşlık Davranışları ve Bu Davranışların Okul Etkililiği Üzerindeki Etkisine İlişkin Algıları. Yayımlanmamış Yüksek Lisans Tezi, Pamukkale Üniversitesi Sosyal Bilimler Enstitüsü, Denizli.

Hoy, W. K. ve Miskel, C. G. (2010). Eğitim Yönetimi: Teori, Araştırma Uygulama, (Çev. Ed. S. Turan), Ankara: Nobel.

Karasar, N. (2003). Bilimsel araştırma yöntemi. (19. Bask1). Ankara: Nobel.

Kayalı, M. (2011). Okul Müdürlerinin Kullandıkları Güç Kaynakları (Uşak İli Örneği). Yayımlanmamış Yüksek Lisans Tezi, Uşak Üniversitesi Sosyal Bilimler Enstitüsü, Uşak.

Kayan, M. (2008). Yaşam Kalitesi ve Örgütsel Vatandaşlık. Yayımlanmamış Yüksek Lisans Tezi, Afyon Kocatepe Üniversitesi Sosyal Bilimler Enstitüsü, Afyonkarahisar.

Korkmaz, C. (2011). İlköğretim ve Ortaöğretim Okullarl Öğretmenlerinin Örgütsel Vatandaşlık Algıları (Malatya İli Örneği). Frrat Üniversitesi Eğitim Bilimleri Enstitüsü, Elazığ.

Koşar, S. (2008). İlköğretim Okulu Yöneticilerinin Yönetimde Gücü Kullanma Stilleri Ile Örgüt Kültürü Arasındaki İlişki. Yayımlanmamış Yüksek Lisans Tezi, Gazi Üniversitesi Eğitim Bilimleri Enstitüsü, Ankara.

Milli Eğitim İstatistikleri Örgün Eğitim $2012 \quad-2013 \quad$ (2014). http://sgb.meb.gov.tr/istatistik/meb_istatistikleri_orgun_egitim_2012_2013.pdf adresinden 12.01.2014 tarihinde alınmıştır.

Nar, O. (2009). İlköğretim Okullarında Görev Yapan Öğretmenlerin Arkadaşlık, Başarl ve Statü Çabaları ve Bu Çabaların Örgütsel Vatandaşlı Davranışlarılyla İlişkisinin Incelenmesi. Yayımlanmamış Yüksek Lisans Tezi, Yeditepe Üniversitesi Sosyal Bilimler Enstitüsü, İstanbul.

Oğuz, E. (2011). Öğretmenlerin Örgütsel Vatandaşlık Davranışları ile Yöneticilerin Liderlik Stilleri Arasındaki İlişki. Kuram ve Uygulamada Eğitim Yönetimi, 17 (3), 377-403.

Özaslan, G. (2006). Eğitim Yöneticilerinin Güç Tipi Tercihlerinin Değerlendirilmesi. Yayımlanmamış Yüksek Lisans Tezi, Selçuk Üniversitesi Sosyal Bilimler Enstitüsü, Konya.

Özaslan, G., Gürsel, M. (2008). Eğitim Yöneticilerinin Güç Tipi Tercihlerinin Değerlendirilmesi. Selçuk Üniversitesi Ahmet Keleşoğlu Eğitim Fakültesi Dergisi, 25, $351-370$. 
Özcan, O. (2008). İlköğretim Öğretmenlerinin Örgütsel Özdeşim, Örgütsel Bağl1lık ve Örgütsel Vatandaşlık Davranışlarının Demografik Özelliklere Göre İncelenmesi. Yayımlanmamış Yüksek Lisans Tezi, Yeditepe Üniversitesi Sosyal Bilimler Enstitüsü, İstanbul.

Özkan, S. O. (2012). Örgütsel Güven İle Örgütsel Vatandaşlık Davranışı Arasındaki İlişki: Kocaeli Emniyet Müdürlüğü Örneği. Yayımlanmamış Yüksek Lisans Tezi, Yalova Üniversitesi Sosyal Bilimler Enstitüsü, Yalova.

Öztürk, H. F. (2009). Okul Yöneticilerinde Örgütsel Ahlaki İklim (Örgütsel Etik), Örgütsel Vatandaşlık ve Örgütsel Bağlllık İlişkisi ( Şişli İlçesi Örneği ). Yayımlanmamış Yüksek Lisans Tezi, Beykent Üniversitesi Sosyal Bilimler Enstitüsü, İstanbul.

Polat, S. (2007). Ortä̈ğretim Öğretmenlerinin Örgütsel Adalet Algllarl, Örgütsel Güven Düzeyleri Ile Örgütsel Vatandaşlık Davranışları Arasındaki İlişki. Yayımlanmamış Doktora Tezi, Kocaeli Üniversitesi Sosyal Bilimler Enstitüsü, Kocaeli.

Polat, S. (2010). Okul öncesi yöneticilerinin kullandıkları yönetsel güç kaynaklarına ilişkin ögretmen algıları ile öğretmen motivasyonu arasındaki ilişki. Yayımlanmamış Yüksek Lisans Tezi, Yeditepe Üniversitesi Sosyal Bilimler Enstitüsü, İstanbul.

Polat, S. ve Celep, C. (2008). Ortaöğretim Öğretmenlerinin Örgütsel Adalet, Örgütsel Güven, Örgütsel Vatandaşlık Davranışlarına İlişkin Algıları. Kuram ve Uygulamada Eğitim Yönetimi, 54, 307-331.

Robbins, S.P. (1994). Örgütsel Davranışın Temelleri, (Çev. S. A. Öztürk), Eskişehir: ETAM

Samancı, S. (2006). Örgütsel İklim ve Örgütsel Vatandaşlık. Yayımlanmamış Yüksek Lisans Tezi, Afyon Kocatepe Üniversitesi Sosyal Bilimler Enstitüsü, Afyonkarahisar.

Schermerhorn, J.R., Jr., Hunt, J.G., \& Osborn, R.N. (2000). Organizational behaviour (7th ed.). USA: John Wiley \& Sons, Inc.

Sezgin, F. ve Kılınç, Ç. A. (2012). İlköğretim Okulu Öğretmenlerinin Mesleki Tükenmişlik Düzeyleri İle Örgütsel Vatandaşlık Davranışları Arasındaki İlişki. Ahi Evran Üniversitesi Kırşehir Eğitim Fakültesi Dergisi (KEFAD), 13 (3), 103-127.

Sezgin, F. (2005). Örgütsel Vatandaşlık Davranışları: Kavramsal Bir Çözümleme ve Okul Açısından Bazı Çıkarımlar. Gazi Eğitim Fakültesi Dergisi, 25 (1), 317-339.

Somech, A. and Drach-Zahavy, A. (2002). Relative Power and Influence Strategy: The Effects of Agent/Target Organizational Power on Superiors' Choices of Influence Strategies. Journal of Organizational Behaviour, 23 (5), 167-179.

Şentürk, C. ve Baş, G. (2011). İlköğretim Okulu Öğretmenlerinin Örgütsel Adalet, Örgütsel Vatandaşlık ve Örgütsel Güven Algıları. Kuram ve Uygulamada Eğitim Yönetimi, 17 (1), 29-62.

Titrek, O. ve Zafer, D. (2009). İlköğretim Okulu Yöneticilerinin Kullandıkları Örgütsel Güç Kaynaklarına İlişkin Öğretmen Görüşleri. Kuram ve Uygulamada Ĕgitim Yönetimi, 15 (60), 657-674.

Titrek, O., Bayrakçı, M. ve Zafer, D. (2009). Öğretmenlerinin Örgütsel Vatandaşlık Davranışlarına İlişkin Görüşleri. Akademik Bakış, 17, 1-28.

Uslu, B. (2011). İlköğretim Okulu Öğretmenlerinin Örgütsel Vatandaşlık Davranışlarl: (Manisa Il Örneği). Yayımlanmamış Yüksek Lisans Tezi, Ege Üniversitesi Sosyal Bilimler Enstitüsü, İzmir. 
Uslu, B., Balc1, E. ve Uslu, A. (2012). İlköğretim Okulu Öğretmenlerinin Örgütsel Vatandaşlık Davranışlarının Bazı Değişkenler Acısından İncelenmesi. Eğitim ve Öğretim Araştırmaları Dergisi, 1 (2), 13-24.

Uzun, E. (2008). Özel ve Devlet Okulu Yöneticilerinin Liderlik Davranışlarının Öğretmen Görüşlerine Göre Karşılaştırılması. Yayımlanmamış Yüksek Lisans Tezi, Yeditepe Üniversitesi Sosyal Bilimler Enstitüsü, İstanbul.

Üstün, S. (2013). Illkokul Kurum Yöneticilerinin Güç Tipi Tercihleri: Mersin İli Merkez Illçelerinde Örnek Bir Uygulama. Yayımlanmamış Yüksek Lisans Tezi, Çağ Üniversitesi Sosyal Bilimler Enstitüsü, Mersin.

Yarım, M. (2009). Genel Liselerde Çalışan Branş Öğretmenlerinin Örgütsel Vatandaşlık Davranışları. Yayımlanmamış Yüksek Lisans Tezi, Yeditepe Üniversitesi Sosyal Bilimler Enstitüsü, İstanbul.

Yılmaz, K. (2012). İlköğretim Okulu Öğretmenlerinin İş Doyumu Düzeyleri İle Örgütsel Vatandaşlık Davranışları Arasındaki İlişki. Anadolu Journal of Educational Sciences International, 2 (2), 1-14.

Yılmaz, K. ve Altınkurt, Y. (2012a). Okul Yöneticilerinin Kullandıkları Güç Kaynakları İle Öğretmenlerin İş Doyumu Arasındaki İlişki. Kastamonu Eğitim Dergisi, 20 (2), 385402.

Zengin, M. (2011). İlköğretim Okullarında Örgütsel Güven İle Öğretmenlerin Örgütsel Vatandaşlık Davranışı Arasındaki İlişki. Yayımlanmamış Yüksek Lisans Tezi, Yüzüncü Y1l Üniversitesi Sosyal Bilimler Enstitüsü, Van. 